\title{
THE EFFECT OF RELATIVE PERFORMANCE EVALUATION ON INVESTMENT EFFICIENCY AND FIRM PERFORMANCE
}

\author{
A Dissertation \\ by \\ FRANCES MEI-LIN SIU TICE
Submitted to the Office of Graduate and Professional Studies of Texas A\&M University
in partial fulfillment of the requirements for the degree of
DOCTOR OF PHILOSOPHY

$\begin{array}{ll}\text { Chair of Committee, } & \text { Senyo Tse } \\ \text { Committee Members, } & \begin{array}{l}\text { Anwer Ahmed } \\ \text { Thomas Omer } \\ \text { Dechun Wang } \\ \text { Asghar Zardkoohi }\end{array} \\ & \begin{array}{l}\text { James Benjamin } \\ \text { Head of Department, }\end{array}\end{array}$

December 2015

Major Subject: Accounting

Copyright 2015 Frances Mei-Lin Siu Tice 


\begin{abstract}
In this study, I examine the effect of explicit relative performance evaluation (RPE) on managers' investment decisions and firm performance. Principal-agent theory suggests that firms can motivate managers to act in shareholders' interest by linking their compensation to firm performance. However, firm performance is often affected by exogenous factors that simultaneously affect peer firms' performance, and therefore, performance-based compensation may expose managers to common risk that they cannot control. In such cases, theoretical models show that firms can improve risk sharing and incentive alignment by compensating managers on performance relative to peers to remove the effect of common shocks. However, RPE may be ineffective in addressing agency costs in practice because firms may select suboptimal peer groups, whether because appropriate peers are unavailable or because managers choose underperforming peers for self-serving reasons. Therefore, the question of whether explicit RPE use in executive compensation reduces agency costs remains unanswered in the empirical literature. I take advantage of expanded disclosures mandated in 2006 by the Securities Exchange Commission to examine whether explicit RPE improves managerial performance as measured by investment efficiency and changes in shareholder wealth.
\end{abstract}

After controlling for selection bias, I find that RPE firms are generally less likely to over- or underinvest than non-RPE firms, consistent with RPE improving decisions and aligning managers' incentives with shareholders' interests. Moreover, firms that 
invest more efficiently have higher future profitability and operating performance than those that underinvest or overinvest. Second, I find that RPE firms do not generally have higher one-year or two-year total shareholder return (TSR) than non-RPE firms in the overall sample after I control for other fundamental determinants. However, RPE firms that specifically contract on TSR have higher performance than non-RPE firms. Finally, I find that RPE firms that choose peers with high common risk have higher returns than non-RPE firms: the positive effects of RPE on firm performance increase with the extent of common risk captured by peers, consistent with the predictions of principal-agent theory. Together, these results suggest that RPE use in CEO compensation plans reduces agency costs and improves incentive alignment. 


\section{DEDICATION}

To my wonderful husband and kids for their endless encouragement, patience, and humor that have saved me more times than I can remember. 


\section{ACKNOWLEDGEMENTS}

I thank my dissertation committee members for guidance and support throughout the course of this research: Senyo Tse (chair), Anwer Ahmed, Thomas Omer, Dechun Wang, and Asghar Zardkoohi. I am also grateful for the helpful comments and suggestions from Adrienne Rhodes, Stevie Neuman, Bree Josefy, Jonathan Rogers, Sarah McVay, and accounting workshop participants at Texas A\&M University, the University of Colorado at Boulder, the University of Washington, and the University of Arizona.

I also give special thanks to Mary Lea McAnally, Asghar Zardkoohi, and Alan Love for encouraging me to pursue a PhD. Without them, I would not have gone down this path and be where I am now. Finally, I gratefully acknowledge financial support from the Mays Business School at Texas A\&M University. 


\section{TABLE OF CONTENTS}

Page

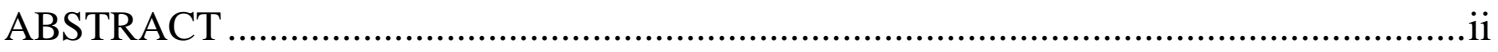

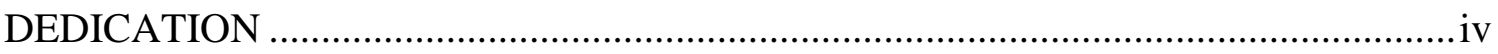

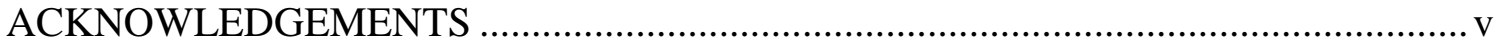

TABLE OF CONTENTS ...............................................................................

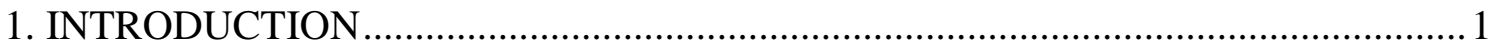

2. BACKGROUND AND HYPOTHESIS DEVELOPMENT .................................... 7

2.1 Prior Literature .............................................................................. 7

2.2 Compensation Contracts with Relative Performance Measures .................... 9

2.3 Hypothesis Development .................................................................... 11

3. SAMPLE SELECTION AND RESEARCH DESIGN ......................................... 18

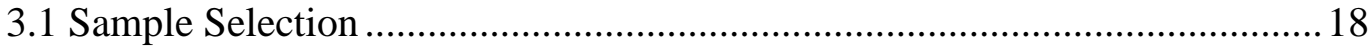

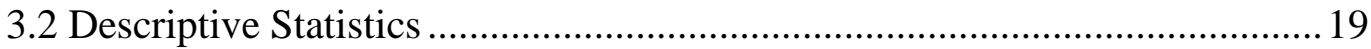

3.3 Research Design ................................................................................ 22

3.3.1 Propensity Score Matching ................................................... 22

3.3.2 Deviation from Expected Investment Levels ................................26

3.3.3 Empirical Specification for Firm Performance ........................... 28

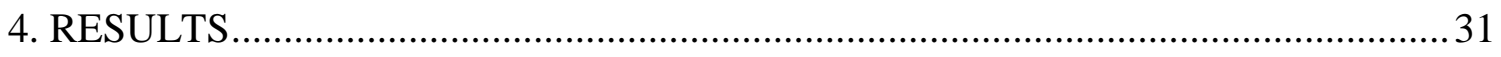

4.1 RPE Use and Investment Efficiency ...................................................... 31

4.1.1 Peer Group Common Risk and Investment Efficiency .................. 32

4.1.2 Evaluating the Investment Efficiency Measure ........................... 35

4.2 RPE Use and Firm Performance .............................................................. 36

4.2.1 Peer Group Common Risk and Firm Performance ....................... 37

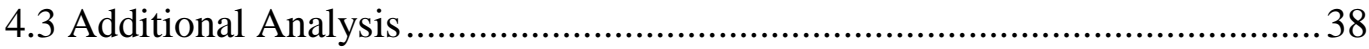

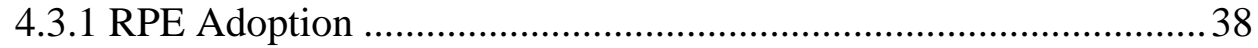




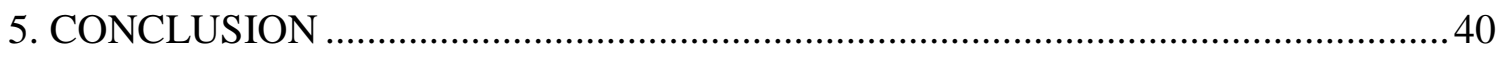

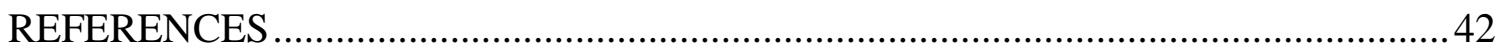

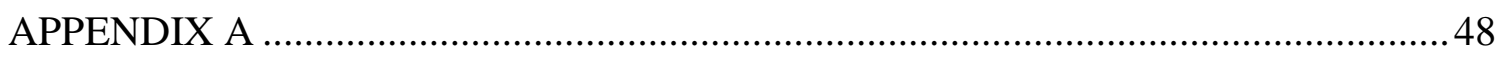

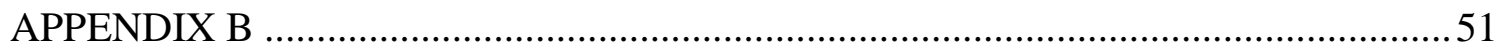

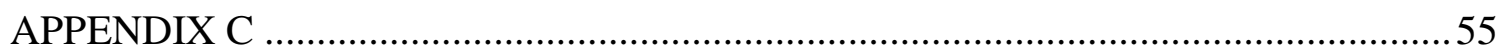




\section{INTRODUCTION}

Principal-agent theory posits that firms can motivate managers to act in shareholders' interest by linking their compensation to firm performance (Holmstrom 1979; Diamond and Verrecchia 1982). However, firm performance is often affected by exogenous factors that also affect the performance of related firms. As a result, performance-based compensation may be ineffective in motivating managers to act in shareholders' interest because it exposes managers to common risk that they cannot directly control. In such cases, Holmstrom (1982) suggests that the optimal incentive scheme would protect the manager from common risk by measuring firm performance relative to that of peer firms. By removing the effect of common shocks from measured performance, relative performance evaluation (RPE) enables the principal to compensate managers on their effort and events under their control. Therefore, RPE should improve risk sharing and incentive alignment, thus enhancing managers' incentives to increase shareholder wealth (Lazear and Rosen 1981; Holmstrom 1982; Nalebuff and Stiglitz 1983; Gibbons and Murphy 1990). In this study, I take advantage of recently mandated disclosures to examine whether the explicit use of RPE in CEO compensation plans improves managers' decisions in terms of investment efficiency and increases firm performance in a manner consistent with reduced agency costs. ${ }^{1}$

\footnotetext{
${ }^{1}$ My study accepts companies' selection of their RPE peers as given and does not investigate how firms do or should select peers.
} 
Understanding the potential effect of RPE use on managerial behavior and firm performance is important for several reasons. First, incentives from relative performance measures differ from those from absolute or fixed measures because managers with RPE contracts are compensated on a benchmark value that is determined ex-post. In addition, over the last several years, an increasing percentage of firms have incorporated RPE in compensation contracts. In my sample, RPE use increases from $22 \%$ in 2006 to $37 \%$ in 2012 for large firms. Finally, RPE awards represent a significant portion of CEO compensation and are therefore likely to influence managerial behavior. For example, Bettis et al. (2014) find that RPE awards represent $32 \%$ of overall compensation. Beginning in 2006, the Securities Exchange Commission (SEC) requires public companies to disclose RPE use and related information about performance benchmarks and peers in their proxy statements. Before this data became available, most archival RPE research inferred RPE use by regressing firms' CEO pay against peer groups' performance (e.g., Antle and Smith 1986; Gibbons and Murphy 1990; Janakiraman et al. 1992; Aggarwal and Samwick 1999; Albuquerque 2009; Albuquerque 2014). As noted by Albuquerque (2009), the literature finds mixed results on detecting RPE use because of measurement error stemming from assumptions made about the performance measures and peer group identification. Gong et al. (2011) and Bettis et al. (2014) utilize the new disclosures to investigate firms' decisions to use RPE and the peers they select. To date, however, the effectiveness of RPE in improving decision-making remains unexplored. 
I obtain detailed data on the new RPE disclosures from the Incentive Lab database over the period 2006 to 2012. Because firms self-select to use RPE, I use a propensity score approach to construct two groups, RPE (treatment) and non-RPE (control) observations, based on factors affecting the likelihood that a firm uses RPE. I then investigate the effect of RPE on managers' behavior. One of the major firm decisions that managers can directly influence is investment in new projects, which includes capital expenditures, research and development, and acquisitions. Prior research suggests that managers whose incentives are misaligned with those of shareholders may either overinvest (e.g., managers accept low-value projects to increase firm size and 'build an empire') or underinvest (e.g., managers forego high-value investments to lower their personal risk or increase short-term income). If RPE strengthens incentive alignment then it should reduce the likelihood of over- or underinvestment. I measure investment efficiency following Richardson (2006) and Biddle et al. (2009), and find that RPE firms are less likely to deviate from expected investment than non-RPE firms, which suggests that RPE improves investment decisions. ${ }^{2}$ Furthermore, I test whether RPE firms' relative investment efficiency increases with the extent to which RPE firms' peers capture common risk. I do not find evidence that the addition of peer-based variables improves on the model specification using an RPE indicator, which suggests that higher investment efficiency is mainly driven by the use of RPE and not necessarily

\footnotetext{
${ }^{2}$ I follow Richardson (2006), Biddle et al. (2009), and Cheng et al. (2013) in focusing on the deviation of firms' total investment from expected levels and do not examine the risk mix of the investments. Thus I do not address the possibility that managers invest at the level predicted by the model but accept projects with a different mix of risk than investors would prefer.
} 
a function of common risk captured by peers. Finally, I evaluate the validity of my proxy for investment efficiency by testing its link to future firm performance and find evidence that firms classified as investing efficiently have higher future profitability and operating performance than those classified as underinvesting or overinvesting.

I also investigate whether RPE increases shareholder wealth by testing whether RPE firms perform better than non-RPE firms. I proxy for firm performance using total shareholder return (TSR) because it directly measures value provided to investors and is used by over $75 \%$ of RPE firms. I compare firm performance for RPE and non-RPE firms after controlling for selection bias by regressing one- and two-year TSR on RPE use along with controls for corporate governance, firm characteristics, and investment opportunity set. I find some evidence that RPE firms that specifically contract on TSR have higher performance than non-RPE firms. In addition, I find that RPE firms that choose peers with high common risk have higher performance than non-RPE firms, which is consistent with the predictions of principal-agent theory. However, RPE firms do not generally perform better than non-RPE firms in the overall sample.

This study makes several contributions to the existing literature. First, I extend the growing empirical literature on relative performance in executive compensation contracts to consider the effects of RPE on managerial decision-making. Before the SEC-mandated data became available in 2006, the literature focused on identifying RPE firms by comparing their CEO compensation with those of various potential peer groups. More recent studies have used the new disclosures to examine the determinants of RPE use and how firms select RPE peers. To my knowledge, this is the first study to directly 
examine whether the explicit use of RPE improves investment decisions and firm performance, consistent with a reduction in agency costs.

My study also contributes to the executive compensation literature that links compensation contracts to managerial behavior. Many studies examine the relation between managerial behavior and compensation plan incentives such as option and equity grants (Larcker 1983; Defeo et al. 1989; Lambert et al. 1989; Sanders 2001; Ittner et al. 2003; McChesney et al. 2005) and specific fixed performance measures (Marquardt and Wiedman 2007; Young and Yang 2011; Shalev et al. 2013; Huang et al. 2013). My study extends this literature by examining the effects of relative performance targets to managers' decisions and performance outcomes.

Finally, my study adds to the literature on the use of peer groups in executive compensation contracts. Firms use peer groups in compensation contracts for two purposes, to benchmark the appropriate level of pay, and to set external performance targets. Much of the existing research on peer groups examines the peers selected for benchmarking pay levels (e.g., Bizjak et al. 2008; Faulkender and Yang 2010; Cadman and Carter 2011; Albuquerque et al. 2013). Peers used in RPE have received less attention, but are important because a portion of the manager's compensation depends on the relative performance of the designated peers. Moreover, the composition of peer groups used for RPE purposes often differs from that of peer groups used in benchmarking pay levels because the groups are used for different purposes within executive compensation contracts (Carter et al. 2009; Gong et al. 2011). Therefore, findings from peer benchmarking studies do not necessarily apply to RPE peers. This 
study fills this void in the peer-group literature by examining the effect of peers groups explicitly used for RPE purposes.

The remainder of the paper is organized as follows. Section 2 discusses prior related literature and hypothesis development. Section 3 presents the descriptive statistics of RPE use in compensation contracts, sample construction, and the research methods used to test my hypotheses. Section 4 reports the results of empirical tests analyzing the effect of RPE use on firm performance and investment decisions. Finally, Section 5 summarizes my findings and their implications. 


\section{BACKGROUND AND HYPOTHESIS DEVELOPMENT}

\subsection{Prior Literature}

Agency costs arise when principals (shareholders) hire agents (managers) to make decisions on their behalf because (1) the two parties' interests are misaligned and (2) information asymmetries prevent the principal from directly observing the managers' effort. Agency theory suggests that the principal can motivate managers to maximize shareholder wealth by tying executive compensation to firm performance (Ross 1973; Jensen and Meckling 1976; Demski and Feltham 1978; Harris and Raviv 1979; Holmstrom 1979, 1982; Diamond and Verrecchia 1982). An extensive line of accounting and finance studies examines the link between compensation contracts and manager behavior. For example, Larcker (1983) finds a positive relation between long-term incentive plans and capital investment levels and Larcker (1987) reports that the adoption of short-term incentive plans affects the mix of discretionary expenditures. This suggests that pay horizon affects CEOs' incentives, which in turn affects the CEOs' spending decisions. Other studies demonstrate that equity ownership is linked to CEOs' preferences for acquisitions over joint ventures (Datta et al. 2009; Datta et al. 2001) and selling, general and administrative expenditures (Banker et al. 2011) while stock options are associated with income smoothing (Grant et al. 2009). Further linking pay to performance, Bettis et al. (2010) examine equity awards that include performance-based vesting conditions and conclude that the specified requirements present meaningful 
hurdles as well as significant incentives for managers. Together, these studies provide evidence that specific compensation package features affect managerial behavior.

In theory, RPE should strengthen the link between CEO pay and firm performance, particularly when the manager is risk-averse and the performance of the firm is affected by exogenous shocks. Most empirical research regarding RPE focuses on the prevalence of relative performance measures in executive compensation packages and offers mixed evidence on whether RPE is used in determining pay. The main challenge in these studies is data availability because firms were not required to disclose RPE use prior to 2006. In the absence of specific disclosure, these studies look for implicit evidence of RPE use by regressing pay on various assumed peer groups, such as market indices (Jensen and Murphy 1990; Aggarwal and Samwick 1999), industry peers, and similarly-sized firms (Bannister and Newman 2003; Albuquerque 2009; Albuquerque 2014). As summarized in Table 1 of Albuquerque (2009), the empirical findings about the prevalence of RPE is mixed, likely because the implicit approach relies on assumptions about RPE contracts (e.g., the peer group selection and the RPE performance measures used) that inevitably lead to measurement error.

While most RPE studies infer RPE use indirectly, several archival studies have examined the explicit disclosure of RPE to understand its prevalence and determinants. For example, Murphy (2000) provides descriptive statistics of RPE use in 177 large U.S. firms included in the 1997 Towers Perrin's Annual Incentive Plan Design Survey that employ RPE in executive compensation contracts. The study also suggests that the abovementioned disagreement on the prevalence of RPE found by studies that identify 
RPE firms using the implicit approach is likely due to model misspecifications and incorrect assumptions about how RPE firms select peer groups. Gong et al. (2011) provides support for this claim, finding that implicit tests are unable to detect RPE use because they lack RPE contract details such as selection criteria and performance metrics. They show that approximately $25 \%$ of their sample disclosed RPE use in 2006.

Tournament theory posits that a rank-order tournament provides an efficient way for principals to evaluate and motivate managers when effort is unobservable (Lazear and Rosen 1981). Prior experimental studies compare performance resulting from tournament (i.e. relative performance) versus individual incentive schemes such as fixed pay or piece-rate. Consistent with theory, these studies generally find that tournaments are effective in reducing overall risk to managers when some risks are common to all managers. This results in higher levels of manager effort in tournaments than individual incentive schemes. For example, Frederickson (1992) shows that participants managing hypothetical production shifts exert more effort when their bonus is based on their performance relative to that of other workers than when they are compensated on an absolute benchmark. Hannan et al. (2008) also find evidence that an incentive scheme based on relative performance is more effective at driving performance than one based on individual performance as long as some risk is common across managers.

\subsection{Compensation Contracts with Relative Performance Measures}

In 2006, the SEC adopted new rules on executive compensation that required public companies to report more detailed descriptions of compensation pay practices in their proxy statements (Final Rule SEC 33-8732a). Using these new disclosures, I 
classify a firm as an RPE firm if at least one component of the CEO's compensation package is explicitly tied to the firm's performance relative to that of peer firms. Otherwise, I classify the firm as a non-RPE firm. ${ }^{3}$

When explicitly using RPE to determine CEO pay, firms are required to disclose their performance measures, goals, and resulting payouts, as well as the identity of the peer firms or market index used for comparison. Under RPE, the award structure and peer group are established at the beginning of the performance period. Relative performance measures can be either accounting-based or market-based. Gong et al. (2011) report that over 70\% of RPE firms in their 2006 sample use stock returns as the performance metric followed by $14 \%$ and $12 \%$ using ROE and sales growth, respectively. Firms may also use more than one performance measure to benchmark relative performance (e.g., a combination of TSR and ROIC). At the end of the performance period, payout levels for the RPE award are typically conditional on achieving specified rankings or percentiles within the peer group or reaching a certain value, such as the average TSR for the S\&P 500 over the performance period.

In my sample, an example of a firm employing RPE is Target Corporation. For the 2010 fiscal year, the long-term equity incentive plan included relative performance requirements for 3-year EPS growth and 3-year market share growth of domestic net sales. Each measure determined half of the stock award. In addition, Target employed a rank-order approach to benchmark performance against 14 other retail companies. The

\footnotetext{
${ }^{3}$ I consider firms that use peer groups to benchmark the level of total compensation, but do not use relative performance targets, to be non-RPE firms.
} 
CEO would receive $100 \%$ payout for reaching the above-median rank of the peer group, increasing to a maximum of $150 \%$ payout for attaining $3^{\text {rd }}$ rank or better and dropping to $0 \%$ payout at $13^{\text {th }}$ rank. Appendix A provides two additional examples of RPE contracts with excerpts from the Compensation Discussion and Analysis (CD\&A).

\subsection{Hypothesis Development}

Performance targets are widely used to evaluate managers' performance because they provide information on managers' actions and also offer monetary incentives for high performance. When establishing benchmarks in compensation contracts, firms may base performance targets on fixed (absolute) benchmarks or the relative performance of peers. In the first case, fixed performance targets are set at the beginning of the period and are typically based on the past performance of a manager (Murphy 2000). The relative performance approach sets the peer group ex ante, but uses the ex-post (actual) performance of a peer group as the metric for evaluating managers.

Although the fixed benchmark method imposes fewer requirements on data availability, it introduces several drawbacks according to contract theory. First, a firm's measured performance is a noisy signal for evaluating managerial actions because it is often affected by common shocks to the market that are beyond managers' control (Holmstrom 1979, 1982; Matsumura and Shin 2006). This creates a risk-sharing problem because managerial performance cannot be assessed easily, which may lead to suboptimal decision-making. This effect is exacerbated when managers are risk-averse because optimal risk-sharing requires that the firm compensate the managers for bearing 
the risk arising from common shocks that are beyond their control (Lazear and Rosen 1981).

Another potential problem of using single firm performance benchmarks is that targets are often set based on past individual performance, which then decreases managers' ex ante incentives to exert effort (Weitzman 1980). This dynamic incentive problem, known as the "ratchet effect," suggests that a manager may withhold some effort in order to meet but not exceed performance targets because the outcome is likely to affect performance targets in the future. This may lead managers to engage in gaming behavior, such as postponing investment decisions or reducing sales, once the current year's benchmarks have been met (Leone and Rock 2002; Bouwens and Kroos 2011). For example, Bouwens and Kroos (2011) document that sales managers who are compensated with fixed targets and have high sales activity in the first three quarters tend to reduce their numbers in the final quarter. In addition, these same individuals are also more likely to meet next year's sales targets relative to those who do not reduce the final quarter's sales.

Given these concerns with fixed performance targets, Holmstrom (1982) suggests that the optimal incentive scheme to motivate managers is to compensate them on firm performance relative to peer performance if the manager is risk-averse and the exogenous shocks affecting firm performance are common across the peer group. RPE removes the systematic risk from firm performance that the manager cannot control, therefore providing the principals with a cleaner assessment of managers' performance. In theory, the use of RPE in compensation contracts should result in better risk-sharing 
and stronger incentive alignment, which should then motivate managers to increase firm value (Lazear and Rosen 1981; Holmstrom 1982; Nalebuff and Stiglitz 1983; Gibbons and Murphy 1990). In practice, firms also cite the need to reduce managers' exposure to systemic risk as a reason for using RPE. For example, Target Corporation adopted RPE in 2009 and stating:

The decision to move to relative measures for PSU payouts is intended to ensure that our compensation performance metrics include not only performance against our own internal absolute benchmarks, but also performance relative to that of our competitors. Absolute measures that were used in the past could be greatly skewed by a rapid downturn or upturn in the economy, rather than reflecting executives' ability to drive performance under those conditions.

Consistent with the notion that companies use RPE to filter out common shocks from performance, Gong et al. (2011) find that RPE firms tend to select peers that have similar risk factors and firm characteristics. Moreover, tournament theory predicts that selecting peers with similar ability should reduce shirking and suboptimal investing (Lazear and Rosen 1981; Hvide 2002). In summary, the explicit use of RPE in compensation contracts should motivate managers to make optimal choices to increase firm value.

One of the major firm decisions that managers can influence is selecting investment projects. Investments include capital expenditures, research and development, and acquisitions, which can ultimately affect future firm performance (e.g., Larcker 1983; Lev and Sougiannis 1996; Chan et al. 2001). Managers whose incentives are misaligned with the interests of shareholders may make investment decisions that maximize their personal welfare but conflict with shareholders' interests 
(Berle and Means 1932; Jensen and Meckling 1976). As such, incentive misalignment can lead to either over- or underinvestment. Managers may overinvest because they are motivated by empire-building. Jensen (1986) and Stulz (1990) posit that such managers prefer to reinvest the firm's free cash flow in negative NPV projects to expand the size of the firm instead of distributing the funds to shareholders. Managers may also overinvest by accepting "pet projects" developed internally or acquired from other firms. For example, Morck et al. (1990) present evidence that self-interested managers may acquire targets that benefit themselves but not shareholders, thus reducing shareholder wealth. ${ }^{4}$ In addition, Titman et al. (2004) shows that firms that substantially increase capital investments subsequently experience lower future stock returns, particularly when firms have high cash flows and low leverage.

The use of RPE in benchmarking firm performance may reduce managers' tendency to overinvest by removing the effect of common shocks from firm performance, thus strengthening incentive alignment. For example, suppose industrywide returns increase because investors increase their growth expectations across the industry. Managers who are evaluated using fixed stock return performance benchmarks are likely to easily meet the established targets even if they accept some low-value investments, and may use the opportunity for empire-building. In contrast, managers evaluated on relative performance would refrain from overinvesting when their industry

\footnotetext{
${ }^{4}$ Morck et al. (1990) posit that unrelated diversification benefits managers by reducing their personal risk at the cost of shareholder wealth. In addition, managers may expand the firm even though shareholder wealth would be higher if managers instead reduced the size of the firm and returned capital to shareholders.
} 
experiences a positive shock because RPE removes the common shock effect from measured performance.

Prior research also argues that incentive misalignment may lead risk-averse managers to underinvest by forgoing some positive NPV projects (e.g., Aggarwal and Samwick 2006). The incentives to underinvest are likely to increase when common shocks that are outside the manager's control increase the variability of the firm's performance. This agency problem suggests that managers incur private costs from investment, and the resulting suboptimal investment ultimately reduce firm value. Consistent with this notion, Aggarwal and Samwick (2006) find that investment increases with incentives. Moreover, their model shows that managers' incentives to maintain suboptimal investment levels increase with their risk aversion and decline with the variance of firm performance. In the above example of a positive industry-wide shock, managers who are evaluated using fixed stock return performance benchmarks may reject some positive NPV projects because they can easily achieve the benchmarks even with inaction. In this case, RPE removes the common shock effect from compensation, thereby strengthening incentive alignment and reducing the likelihood of undervesting relative to non-RPE schemes.

Despite these theoretical benefits, RPE use as implemented in practice may not be effective in addressing agency costs. The benefit of RPE hinges on peer performance capturing common shocks that are beyond managers' control. Thus, firms operating across multiple business segments may have difficulty selecting a peer group that is subject to similar shocks. In addition, tournament theory suggests that firms should 
select peers whose abilities are similar to those of the focal firm to prevent unequal comparisons that may result in shirking. Gong et al. (2011) find some evidence that peer selection may reduce RPE effectiveness. Using analyst forecasts, they report that RPE firms often choose peers that are expected to trail industry performance, suggesting a self-serving bias in peer selection. Therefore, it is not clear ex ante whether RPE use as implemented in compensation contracts successfully reduces the tendency to over- or underinvest when compared to non-RPE firms. I state the first hypothesis in the null form:

H1: $\quad$ Firms that explicitly use RPE are as likely to overinvest or underinvest as firms that do not use RPE.

Investments are one of many areas that may be affected by managerial incentives and subsequent behavior. Together, these decisions ultimately flow into overall firm performance, which directly impacts shareholder wealth. If RPE is effective in improving incentive alignment, I expect that managers of RPE firms are motivated to make decisions that will maximize shareholder wealth. However, given the potential costs of RPE as well as the mixed results from Gong et al. (2011) on peer selection choice, RPE as implemented in practice may not result in more value-adding behavior than non-RPE firms. I state the second hypothesis for firm performance in the null form:

H2a: Firms that explicitly incorporate RPE in CEO compensation contracts do not perform better than similar firms that do not use RPE.

Firms using RPE may contract on a range of performance metrics, including market- and accounting-based metrics. Ideally, firms would select RPE metrics that best motivate managers to maximize the firm value. However, prior literature suggests that 
managers often focus only on improving the selected performance measure and take actions consistent with those incentives. For example, Wallace (1997) shows that firms adopting compensation plans based on residual income measures are more likely to report higher residual income, but have lower investment levels, increased disposition of assets, and increased share purchases than other firms. With regard to market-measures, Marquardt and Wiedman (2007) find that managers are more likely to employ convertible bond transactions to increase diluted EPS while Young and Yang (2011) report increased stock repurchases when EPS is explicitly used as the performance target in bonus plans. As a result, these firms may report higher performance when defined by the specified metric, but not necessarily by other performance measures. Given the idea that "you get what you measure," I hypothesize that RPE firms are more likely to have higher firm performance for the performance metric included in the RPE contract and state the directional hypothesis as follows:

H2b: Firms that explicitly incorporate RPE in CEO compensation contracts perform better than similar non-RPE firms on the contracted performance metric. 


\section{SAMPLE SELECTION AND RESEARCH DESIGN}

\subsection{Sample Selection}

I present all tables referenced in the manuscript in Appendix C. Table 1

summarizes sample construction. I start with 8,493 firm-year observations reported in Incentive Lab with compensation contract data between 2006 and 2012. Incentive Lab provides detailed data on compensation plans disclosed in proxy statements for the largest 750 firms for each year using the market value of equity. In addition, the database backfills and forward-fills data for firms entering and leaving the group of largest firms. Because the SEC's new disclosure rules for executive compensation became effective on December 15, 2006, I include only observations with fiscal years ending on or after this mandatory compliance date. This data step reduces the number of observations in the 2006 calendar year from 1,293 firms to 956 firms (26\%). Therefore, my sample retains most of the 2006 firms after conditioning on mandatory disclosure of compensation contracts. I drop firm-year observations missing data to construct the variables required in the propensity-score model (see Equation 1). I obtain financial data from Compustat, market data from CRSP, CEO characteristics (age) from Execucomp, institutional ownership data from Thomson-Reuters Institutional Holdings (13F), and information on the board of directors from BoardEx. My sample of firm-year observations available for propensity score matching is 5,247 . The number of observations per year ranges from 591 for 2006 to 801 for 2010 with an average of 750 firms. As detailed in Panel B in Table 1, I create a propensity-matched sample for RPE and non-RPE firms with data 
available for investment efficiency variables. I also construct a second propensitymatched sample for the firm performance analysis. My main samples for testing investment efficiency and firm performance consist of 1,812 firm-year observations and 2,030 firm-year observations, respectively.

\subsection{Descriptive Statistics}

I report descriptive statistics on RPE use in CEO compensation contracts in Table 2 for all firm-year observations with available data in Incentive Lab between 2006 (on or after December $15^{\text {th }}$ ) and 2012. I classify a firm as using RPE in a given firm-year if they measure performance relative to the performance of a defined peer group or specific index to determine compensation amounts awarded to the CEO. Table 2, Panel A, indicates that $25.8 \%$ of the sample (2,106 out of 8,156 firm-years) explicitly contract on relative performance measures. In comparison, Bannister and Newman (2003) find that $28 \%$ of their sample of 160 firms disclose RPE use in compensation committee reports in 1992, and Gong et al. (2011) report that 25\% of their 2006 sample use RPE. Therefore, the frequency of RPE use in my sample is consistent with prior studies. I also find that the percentage of firms using RPE generally increases over the sample period, in particular in 2010, 2011, and 2012.

Table 2, Panels B, C, and D, provide additional descriptive data for RPE firms. The number of RPE metrics included in the compensation contract varies with $82.86 \%$ of RPE firms using only one relative performance metric and $12.58 \%$ of RPE firms using two relative performance metrics (Panel B, Table 2). In addition, most RPE firms use relative performance in equity-only awards over my sample period $(1,364$ of 2,106 
observations or $64.8 \%$ ). Panel $\mathrm{C}$ indicates that, of this equity-only subsample, RPE is used overwhelmingly for restricted stock (1,336 firms). I find that 58.4\% of RPE firms use relative performance for equity in 2006, which is consistent with Gong et al. (2011) who report $59 \%$. The frequency of RPE use in equity-only awards increases to $70.7 \%$ in 2012. In contrast, the percentage of RPE firms using relative performance in cash-only awards decreases from $30.6 \%$ in 2006 to $18.9 \%$ in 2012. This trend, along with the increasing frequency of RPE use from Panel A, suggests that more firms are tying CEO compensation to relative performance measures in recent years while increasing CEO equity incentives. Finally, Panel D reports the types of peer groups used by firms to benchmark performance. Most RPE firms measure performance against a single custom group of firms or index. Many firms choose a self-selected, custom peer group (65.5\%). Of the established indices, the most commonly used index is the S\&P 500 (9.6\%). I also find that $17.4 \%$ of RPE firms benchmark against other indices $(17.4 \%)$, such as the S\&P 100, S\&P 500 Property and Casualty index, or the NAREIT composite index.

RPE firms benchmark relative performance using accounting- or market-based metrics. Table 3 summarizes the RPE measures disclosed in compensation plans. As shown in Panel A, TSR is used by $77.5 \%$ of all firm-year observations that incorporate RPE in CEO compensation plans followed by ROIC (7.9\%) and EPS growth $(6.7 \%){ }^{5}$ The percentages in Panel A sum to slightly more than $100 \%$ because compensation plans

\footnotetext{
${ }^{5}$ For performance metrics, Incentive Lab separately lists return on invested capital (ROIC) and return on investment (ROI). However, I combine both into a single classification, ROIC, based on the similar construction of the two measures described in proxy statements.
} 
may include more than one RPE metric per year as reported in Table 2. Panel B of Table 3 reports the combination of RPE performance metrics used by firm-years that contract on one or two RPE measures. ${ }^{6}$ This subsample accounts for over $95 \%$ of all firms employing RPE in my sample. When considering only firm-year observations using one or two RPE metrics, I find that $78 \%$ of the RPE firms in this subsample use TSR. ROIC and EPS growth follow in prevalence with RPE metrics at $6 \%$ and $5 \%$, respectively. RPE firms contracting on TSR often select ROIC as their second measure if they use two more RPE metrics in the compensation contract.

Table 4 provides summary statistics on performance, firm characteristics, and corporate governance variables used in the investment efficiency and firm performance analyses. The investment efficiency sample includes 907 RPE firm-years and 907 nonRPE firm-years matched using the propensity-score model described in the following Research Design section and conditioned on data availability to construct variables required in the investment efficiency analysis. The mean (median) values for $B M_{t-1}$ are for RPE and non-RPE observations are $0.656(0.636)$ and $0.644(0.638)$, respectively. In addition, the average ratio of PPE to total assets (TANGIBILITY $\left.{ }_{t-1}\right)$ and length of the operating cycle (OP_CYCLE $t-1$ ) are 0.305 and 4.665 for RPE firms, which is consistent with Biddle et al. (2009). Similarly, non-RPE firms have mean values of 0.315 and 4.660 for TANGIBILITY $_{t-1}$ and OP_CYCLE ${ }_{t-1}$. Overall, RPE firms do not appear to have

\footnotetext{
${ }^{6}$ The diagonal values in the table are the number of firms that use only the specified RPE metric. The totals at the bottom of the table are the sum of each column.
} 
significantly different characteristics that affect investment efficiency compared to nonRPE firms.

I also report the summary statistics for variables used in the firm performance multivariate analysis, which includes 1,015 RPE firm-years and 1,015 non-RPE firmyears matched using the propensity-score model and conditioned on data availability to construct variables required in the firm performance analysis. $75 \%$ of firm-year observations using RPE in this subsample contract on TSR performance, which is similar to the rate of the overall sample. In addition, $84 \%$ of the RPE firms measure relative performance over a period of three years or less (not shown in table). The mean (median) one-year TSR performance is $10.0 \%$ (8.0\%) for RPE firms and $8.0 \%(8.2 \%)$ for non-RPE firms, which are not statistically different. In addition, RPE firms have marginally lower leverage (difference of 0.014 , p-value $<0.10$ ) and are older (difference of 1.674 years, p-value <0.10) compared to non-RPE firms. I control for these differences along with the other factors that can affect firm performance in multivariate tests (Tables 8 and 9).

\subsection{Research Design}

\subsubsection{Propensity Score Matching}

To test whether RPE use affects investment efficiency and firm performance, I first employ a propensity score matching approach to create a matched sample of RPE (treatment) and non-RPE (control) firm-year observations based on several factors affecting the decision to incorporate RPE in CEO compensation contracts. Estimation of a causal effect in observational studies may be biased because firms choose 
compensation methods endogenously. Consequently, differences in outcome may be attributed to factors that affect the likelihood of choosing a compensation method and not the actual method itself. Propensity score matching addresses sample selection bias by creating a matched sample of RPE and non-RPE firms based on their propensity to use RPE (Rosenbaum and Rubin 1983; Dehejia and Wahba 2002). ${ }^{7}$

For the propensity-score model, I estimate the probability of including RPE in CEO compensation contracts in a logistic regression based on a set of industry, firm, $\mathrm{CEO}$, and corporate governance factors that affect the decision to incorporate RPE (Gong et al. 2011). I match RPE firm-year observations (treated) to non-RPE firm-year observations (control) without replacement based on closest propensity score match and a caliper width equal to 0.05 , which is $20 \%$ of the standard deviation of the propensity

\footnotetext{
${ }^{7}$ The results and inferences are similar when using the Heckman Inverse Mills Ratio method to address selection bias.
} 
score. ${ }^{8}$ Because this matching approach depends on the order of the observations, I randomize the order prior to matching by propensity scores. ${ }^{9}$ The model is as follows:

$$
\begin{aligned}
& \operatorname{Pr}\left(R P E_{t}=1\right)=\beta_{0}+\beta_{1} C O M M O N \_R I S K_{t-1}+\beta_{2} S I Z E \_R K A D J_{t-1}+ \\
& \beta_{3} \text { DIVERSITY_RKADJ }{ }_{t-1} \\
& +\beta_{4} R E T U R N_{-} R K A D J_{t-1}+\beta_{5} I N D U S T R Y_{-} C O N C E N T R A T I O N_{t-1}+ \\
& \beta_{6} B M_{t-1} \\
& +\beta_{7} M V E_{t-1}+\beta_{8} R O A_{-} I N D A D J_{t-1}+\beta_{9} R E T U R N_{-} I N D A D J_{t-1} \\
& +\beta_{10} C E O \_W E A L T H_{t-1}+\beta_{11} C E O \_A G E_{t-1}+\beta_{12} T O P 5 \_I N S T O W N_{t-1} \\
& +\beta_{13} A C T I V I S T \_I N S T O W N_{t-1}+\beta_{14} C E O-C H A I R_{t-1}+\beta_{15} B R D_{-} I N D E P_{t-1} \\
& +\beta_{16} B R D \_S I Z E_{t-1}+\beta_{17} \text { COMPCONSULTANT } t-1+\varepsilon .
\end{aligned}
$$

The dependent variable, RPE, is an indicator variable equal to 1 for firm-year observations that explicitly incorporate RPE in CEO compensation contracts in year $\mathrm{t}$ and 0 otherwise. The independent variables in Equation (1) are measured in the year t-1. To capture industry factors that may affect the choice to use RPE, I include variables for the amount of firm risk that can be attributed to common risk within a firm's industry (COMMON_RISK), the availability of similar peers for the firm (SIZE_RKADJ, DIVERSITY_RKADJ, and RETURN_RKADJ), and market competitiveness (INDUSTRY_CONCENTRATION). Firm-level variables measure growth opportunities using book-to-market $(B M)$, firm size using log of market value of equity (MVE),

\footnotetext{
${ }^{8}$ I obtain similar results when matching with a tighter caliper of 0.01 .

${ }^{9} \mathrm{I}$ iterate the matching procedure 100 times to ensure that inferences are not sensitive to the order of the match. The matched samples are identical after resampling, and therefore I do not find evidence that the results from subsequent multivariate analyses are sensitive to matching.
} 
industry-adjusted ROA (ROA_INDADJ), and industry-adjusted returns (RETURN_INDADJ). I measure CEO attributes using the value of the CEO equity holdings (CEO_WEALTH) and CEO age (CEO_AGE). Governance variables include institutional ownership concentration using the ratio of stock owned by the top five institutions over total institutional ownership for the firm (TOP5_INSTOWN), the ratio of stock owned by activist institutions over total institutional ownership for the firm (ACTIVIST_INSTOWN), CEO/Chairman of the Board duality (CEO-CHAIR), the percentage of independent directors serving on the board of directors (BRD_INDEP), and total number of directors on the board $\left(B R D \_S I Z E\right) .{ }^{10}$ Finally, I include an indicator variable, COMPCONSULTANT, equal to 1 when the firm uses a compensation consultant to determine executive pay. The variables are further defined in Appendix B. The above model is estimated with fixed effects for year and industry.

Table 5 compares the mean values of the selection variables in Equation (1) between RPE firms and non-RPE. Panel A reports the difference in means for the full cross-section of firms. After conditioning on the data availability for the independent variables in Equation (1), this sample consists of 3,260 non-RPE firm-year observations and 1,385 RPE firm-year observations. I find that, on average, non-RPE and RPE firms differ significantly on all measured dimensions with the exception of institutional ownership concentration (TOP5_INSTOWN). This suggests that interpreting causal effects without matching may be problematic because, on average, RPE and non-RPE

\footnotetext{
${ }^{10}$ I follow Cremers and Nair (2005) in determining activist institutions.
} 
firms differ substantially on the factors affecting RPE choice. ${ }^{11}$ Panel B compares selection determinants for the propensity-matched sample of non-RPE and RPE firms. The area under the ROC curve for the selection model is 0.82 , which indicates a good model fit. To assess the covariate balance between the non-RPE and RPE groups after matching on the propensity score, I examine the difference in means across the two groups, as well as Kolmogorov-Smirnov tests of the equality of distributions for the continuous variables. The results in Panel B show that the means are not statistically different between the treatment and control groups for any variable. In addition, the distributions are similar for 12 of the 15 continuous variables at the $5 \%$ level. Overall, the tests of difference in means and distribution suggest that the propensity score matching procedure is successful in achieving covariate balance. ${ }^{12}$

\subsubsection{Deviation from Expected Investment Levels}

Having controlled for the choice to use RPE, I test whether RPE use affects investment decisions by examining the deviation from expected investment levels using an investment efficiency measure similar to Richardson (2006) and Biddle et al. (2009). The concept underlying the investment efficiency measure is that firms investing efficiently will undertake all positive NPV projects. To create my measure of investment efficiency, I first estimate the total investment per firm as a function of several factors

\footnotetext{
11 The differences in means between non-RPE and RPE firms for the determinants are consistent with the predictions and findings of Gong et al. (2011).

12 The results for covariate balancing testing are similar for the other matched samples used in multivariate analysis. In addition, inclusion of the three variables that have statistically different distributions as controls in the main models do not change the inferences of the empirical tests.
} 
that have been shown by prior research to affect firm-level investment decisions. The model is:

$$
\begin{aligned}
\operatorname{INVESTMENT}_{t}= & \beta_{0}+\beta_{1} \text { SALES_GROWTH } H_{t-1}+\beta_{2} L_{E} \text { EVERAGE } E_{t-1}+\beta_{3} \text { CASH }_{t-1} \\
& +\beta_{4} F I R M_{-} A G E_{t-1}+\beta_{5} M V E_{t-1}+\beta_{6} I N V E S T M E N T_{t-1}+\varepsilon .
\end{aligned}
$$

Total investment, INVESTMENT , is the sum of capital expenditures, acquisitions, and R\&D, less the sale of property, plant, and equipment in the year of interest. The advantage of this definition of investment is that it includes several types of investments. For firm-level determinants of investment decisions, I include lagged measures of sales growth (SALES_GROWTH $\left.H_{t-1}\right)$, leverage (LEVERAGE $\left.E_{t-1}\right)$, level of cash $\left(C A S H_{t-1}\right)$, firm age $\left(F I R M_{-} A G E_{t-1}\right)$, and firm size $\left(M V E_{t-1}\right)$. Prior studies show that firmlevel investment decisions are sensitive to these measures (e.g., Lamont 1997; Hubbard 1998; Lamont 2000; Bates 2005). I also include the total investment from the prior year (INVESTMENT $\left.T_{t-1}\right)$ because the firm's decision to invest in the current year may dependent on its previous investment. These variables are defined in Appendix B.

I estimate Equation (2) for each industry-year (2-digit SIC) with at least 15 observations. The residual from the estimation model is the firm's deviation from expected investment. Therefore, firms with large positive residuals are likely to be overinvesting whereas those with large negative residuals are likely to be underinvesting. I classify firms into quartiles each year based on the magnitude of the residuals: (1) observations in the highest quartile are considered overinvesting firms; (2) observations in the lowest quartile are considered underinvesting firms; and (3) 
observations in the middle quartiles are the benchmark group. To examine the effect of RPE use on investment efficiency, I test the likelihood that a firm will over- or underinvest using a multinomial logistic model:

$$
\begin{aligned}
& I N V_{-} E F F_{t}=\beta_{0}+\beta_{1} R P E_{t}+\beta_{2} A_{S S E T S} S_{t-1}+\beta_{3} B M_{t-1}+\beta_{4} \text { TANGIBILITY }_{t-1} \\
& +\beta_{5} C A S H_{-} F L O W_{t-1}+\beta_{6} S L A C K_{t-1}+\beta_{7} O P_{-} C Y C L E_{t-1}+\beta_{8} L O S S_{t-1} \\
& +\beta_{9} \text { DIVIDENDS } S_{t-1}+\beta_{10 \sigma C A S H_{-}} \text {LLOW } W_{t-1}+\beta_{11} \sigma S A L E S_{t-1}+ \\
& \beta_{12} \sigma I N V E S T M E N T_{t-1}+\beta_{13} B R D \_S I Z E_{t}+\beta_{14} B R D \_I N D E P_{t}+\beta_{15} C E O- \\
& \text { CHAIR }_{t}+\beta_{16 I N S T O W N} \\
& +\beta_{17} \operatorname{ANALYSTS}_{t}+\varepsilon
\end{aligned}
$$

The dependent variable, $I N V_{-} E F F_{t}$, is equal to 0 for the benchmark group, 1 for the firms investing below the expected levels, and 2 for the firms investing above the expected levels. $R P E$ is an indicator variable equal to 1 when the firm-year observation reports a RPE component in its CEO compensation plan for year $t$, and 0 otherwise. I also include a set of control variables for corporate governance, business cycle, and operating volatility following Biddle et al. (2009).

\subsubsection{Empirical Specification for Firm Performance}

To investigate the effect of RPE use on firm performance, I estimate the following regression of firm performance as a function of RPE use (RPE) and control variables using the propensity-matched samples constructed from the propensity-score model specified in Equation (1): 


$$
\begin{gathered}
\text { FIRM_PERFORMANCE } E_{t}=\beta_{0}+\beta_{1} R P E_{t}+\beta_{2} B R D \_S I Z E_{t}+\beta_{3} B R D \_I N D E P_{t} \\
+\beta_{4} L E V E R A G E_{t}+\beta_{5} F I R M \_A G E_{t}+\beta_{6} M V E_{t}+ \\
\beta_{7} F I R M \_P E R F O R M A N C E_{t-1}+\beta_{8} I O S_{t}+\varepsilon .
\end{gathered}
$$

I measure firm performance as total stockholder return (TSR) because it is the most commonly contracted RPE metric. TSR is a tangible measure of value provided to investors and is a direct evaluation of interest alignment between managers and shareholders. In addition, the calculation of TSR performance is more standardized across firms than other relative performance measures, such as return on invested capital. Consistent with formulas disclosed in proxy statements, I calculate TSR as the change in stock price (ending share price minus beginning share price) plus aggregate dividend payments over the performance period divided by the stock price at the beginning of the performance period.

Consistent with the previous equations, $R P E$ is an indicator variable equal to 1 when the firm-year observation explicitly reports an RPE component in its CEO compensation plan for year $t$, and 0 otherwise. I also control for board and firm characteristics that may affect firm performance. Board of director variables include board size $\left(B R D \_S I Z E\right)$ and board independence $\left(B R D \_I N D E P\right)$. For firm characteristics, I include leverage ratio (LEVERAGE) calculated as total debt divided by total assets, firm age (FIRM_AGE), the log of market value of equity $(M V E)$ for firm size, 1-year lagged TSR performance, and investment opportunity set (IOS). I follow the methodology in Baber et al. (1996) in defining IOS as a broad construct that measures a firm's ability to successfully pursue different growth options. This measure of IOS 
considers growth opportunities stemming from research and development activities, discretionary expenditures in acquisitions, capacity expansions, restructuring of existing assets, and product branding through advertising. Finally, I estimate Equation (2) with fixed effects for year and industry to account for heterogeneity across time and industry and adjust standard errors by clustering on firm. All continuous variables are winsorized at the 1 st and 99th percentiles.

I estimate Equation (4) on three propensity-matched samples. First, I use the full matched sample of non-RPE and RPE firms to estimate the average effect of RPE use on firm performance regardless of which measures are included in the compensation contract. I then re-estimate Equation (2) using a subsample of RPE firms that specifically contract on relative TSR and non-RPE firms to test Hypothesis 2b. Lastly, I use a subsample of RPE firms contracting on TSR and non-RPE firms using TSR as an absolute performance measure in order to hold the performance metric constant and vary the benchmarking approach. 


\section{RESULTS}

\subsection{RPE Use and Investment Efficiency}

To test my first hypothesis, I examine the likelihood of a firm deviating from expected investment as a function of RPE use. Table 6, Panel A, presents the multinomial logistic regression results on investment efficiency from the model specified in Equation (3). I examine underinvestment in Column 1 and overinvestment in Column 2. In Column 1, I find a negative and significant coefficient for $R P E(-0.408$, p-value $<0.01)$. This suggests that RPE firms are generally less likely to invest suboptimally than non-RPE firms. In addition, the likelihood of underinvestment decreases with higher book-to-market and tangibility in year t-1. In terms of economic significance, the probability of underinvesting is 2.3 percentage points lower for RPE firms compared to non-RPE first, holding all continuous variables at means and indicator variables at median values. In comparison, the probability of underinvesting is 4.2 percentage points lower when moving from the $25^{\text {th }}$ to the $75^{\text {th }}$ percentiles in TANGIBILITY $_{\mathrm{t}-1}$, holding all continuous variables at means, indicator variables at median values, and $R P E=1$. For book-to-market, the probability of underinvesting is 14.2 percentage points lower when moving from the $25^{\text {th }}$ to the $75^{\text {th }}$ percentiles, holding all continuous variables at means, indicator variables at median values, and $R P E=1$.

I also find that on average RPE firms are less likely to overinvest as indicated by the negative and significant coefficient for $R P E(-0.408$, p-value $<0.01)$ in Column 2. Firms with longer operating cycles or incurred a loss in the previous year also are less 
likely to overinvest. The probability of overinvesting is 1.6 percentage points lower for RPE firms compared to non-RPE first, holding all continuous variables at means and indicator variables at median values. In comparison, the probability of overinvesting is 6.7 percentage points lower when moving from the $25^{\text {th }}$ to the $75^{\text {th }}$ percentiles in OP_CYCLE $\mathrm{t}_{\mathrm{t}-1}$, holding all continuous variables at means, indicator variables at median values, and $R P E=1$. Similarly, I find that the probability of overinvesting is 1.6 percentage points lower when firm-year observations incur a loss in the previous year, holding all continuous variables at means, indicator variables at median values, and $R P E$ $=1$. The economic significance results suggest that while other firm characteristics have a significant effect on investment efficiency, RPE can still be used to move managers towards optimal investment levels. ${ }^{13}$ This is consistent with the idea that RPE use in compensation plans strengthens the interest alignment between the interests of managers and shareholders.

\subsubsection{Peer Group Common Risk and Investment Efficiency}

Principal-agent theory suggests that RPE should improve the evaluation of managers' actions by removing common exogenous shocks that are beyond the managers' control, resulting in more efficient contracting and better incentive alignment. In theory, RPE is more effective in motivating managers when peer performance provides more information about managers' actions than firm performance alone (Holmstrom 1979, 1982; Baiman and Demski 1980). Consistent with this concept,

\footnotetext{
${ }^{13}$ I find similar results for economic significance when holding all other variables to median values.
} 
Frederickson (1992) demonstrates experimentally that study participants increase effort as common risk increases under an RPE contract, but not under a non-RPE (i.e. absolute performance benchmark) contract. Therefore, I test whether the positive effect of RPE on investment efficiency is dependent on the extent of common risk by examining the relation between RPE use and deviation from expected investment levels conditional on the amount of common risk captured by the custom peer group.

For this set of analyses, I identify RPE firms that specify a custom peer group and match them to non-RPE firms using the propensity-score model in Equation (1). The propensity-matched sample consists of 1,212 firm-year observations. I measure the amount of common risk captured by the peer group, PEER_COMMONRISK, using the R-squared from a regression of the firm's stock returns over the prior 36 months on the average returns of the peer group. PEER_COMMONRISK is set to zero for non-RPE firms because no common risk is filtered out for firm performance. ${ }^{14}$ In my sample of RPE firms that use custom peer groups, I find that the extent to which peer firms capture common risk in the RPE firm varies significantly. In untabulated summary statistics, I find that PEER_COMMONRISK ranges from 0.014 to 0.865 with a mean of 0.513 and a median of 0.545 . I also control for the degree of similarity between the peer firms and RPE firm because tournament theory predicts that selecting peers with lower ability may reduce RPE benefits (Lazear and Rosen 1981; Hvide 2002). I define

\footnotetext{
${ }^{14}$ In unreported analysis, I also use two alternative proxies for common risk captured by the selected peer group: (1) the correlation between the firm's stock returns over the prior 36 months and the average returns of the peer group, and (2) the coefficient from a regression of the firm's stock returns over the prior 36 months on the average returns of the peer group. The subsequent results and conclusions are similar using the alternative proxies.
} 
PEER_DISSIMILARITY as the absolute difference between the firm's market capitalization and the average for the peer group in year t-1; as constructed, PEER_DISSIMILARITY increases as firms become less similar in ability. PEER_DISSIMILARITY is set to zero for non-RPE firms. In untabulated summary statistics, I find that PEER_DISSIMILARITY ranges from 0.056 to 138.301 with a mean of 10.557 and a median of 3.837 .

Table 6, Panel B, reports the regression results for the likelihood of over or underinvesting for the subset of RPE firms that use custom peer groups and the control firms. Columns (1) and (2) report the results of the multinomial logistic regression of investment efficiency as a function of common risk captured by the selected peers. I find that the coefficient for PEER_COMMONRISK is negative and significant for the likelihood of underinvesting $(-1.284$, p-value < 0.01$)$ and the likelihood of overinvesting (-0.922, p-value < 0.01). The coefficient for PEER_DISSIMILARITY is not significant for either underinvestment or overinvestment, however.

I also re-estimate the investment efficiency as a function of the indicator of RPE use (RPE) for this subsample (Columns (3) and (4)). The coefficients for $R P E$ remain negative and significant for both the likelihood of underinvestment and overinvestment, which is consistent with the idea that RPE use moves managers to higher investment efficiency. To understand whether the common risk captured by selected peers affects investment efficiency beyond the use of RPE in compensation plans, I compare Akaike's information criterion (AIC) and Bayesian information criterion (BIC) of the two specifications, and find that the model using the RPE indicator has smaller AIC and BIC 
values than the larger model incorporating common risk and peer dissimilarity variables. Therefore the addition of peer-based variables does not improve on the model specification, which suggests that higher investment efficiency is mainly driven by the use of RPE and not necessarily a function of common risk captured by peers.

\subsubsection{Evaluating the Investment Efficiency Measure}

To determine whether the measure of investment efficiency using the deviation from expected investment levels by industry-year captures the construct of investment efficiency, I estimate the relation between this proxy and future firm performance using firms from my 2006-2012 sample that have data available to construct the investment efficiency and lead performance variables. Conceptually, investing efficiently should lead to higher future profitability and operating performance compared to over- or under-investing because firms that invest efficiently undertake all projects with positive NPV instead of passing on investment opportunities with positive NPV (underinvesting) or investing in projects with negative NPV (over-investing). I measure investment efficiency in year $t$ and examine changes in firm performance over two and three year periods beginning in year $\mathrm{t}-1$ using three proxies - return on assets (ROA) growth, earnings per share (EPS) growth, and change in Tobin's Q. For ROA growth, I define ROAGROWTH_2YR(ROAGROWTH_3YR) as the change in ROA between year $\mathrm{t}+1(\mathrm{t}+2)$ and year $\mathrm{t}-1$ divided by the absolute value of ROA in year $\mathrm{t}-1$. Similarly, I define EPSGROWTH_2YR (EPSGROWTH_3YR) for EPS growth as the change in EPS between year $t+1(t+2)$ and year $t-1$ divided by the absolute value of EPS in year $t-1$. Finally, I measure the change in firm value using $\triangle T O B I N \_2 Y R\left(\triangle T O B I N \_3 Y R\right)$, which 
is calculated as the as the change in Tobin's $Q$ between the end of year $t+1(t+2)$ and beginning of year $t$ divided by Tobin's $Q$ at the beginning of year $t$.

Table 6, Panel C, presents the univariate results. I find that firms classified as investing efficiently tend to have higher 2-year EPS growth and higher increase in Tobin's Q than those that are classified as underinvesting over 2-year and 3-year periods. In addition, firms that invest efficiently also have higher 2-year and 3-year ROA growth, higher EPS growth, and higher increase in Tobin's Q than firms that are classified as overinvesting. Together, the results suggest that efficient investing is associated with higher future profitability and operating performance.

\subsection{RPE Use and Firm Performance}

In my next analysis, I investigate whether the benefits of RPE use are reflected in overall firm performance. Table 7 presents the regression results for firm performance as defined by the most frequently used RPE metric, TSR, for propensity-matched RPE/nonRPE samples. In Panel A, I compare the effect of RPE on one- and two-year TSR using the full matched sample of RPE and non-RPE firms. The coefficient on $R P E$ is not statistically significant for either one- or two-year TSR. This result suggests that RPE firms do not generally have higher TSR than non-RPE firms. Panel B presents regression results examining whether performance differs across RPE and non-RPE firms that specifically contract on TSR. Consistent with Hypothesis $2 b$, I find that these RPE firms have higher 1-year TSR performance than non-RPE firms as indicated by the positive and significant coefficient for $R P E(0.037$, p-value < 0.05$)$. However, this positive effect of RPE on performance does not hold for 2-year TSR performance. Finally, Panel C 
reports the regression results for the sample of RPE that contract on TSR and non-RPE firms that contract on TSR as an absolute benchmark. I find that the coefficient for $R P E$ is positive and statistically significant for both 1-year TSR and 2-year TSR estimations. ${ }^{15}$

Based on the results from Table 7, I cannot reject the null in Hypothesis $2 \mathrm{a}$ and find that RPE firms do not generally demonstrate higher performance than non-RPE firms. I find some evidence that RPE firms have higher performance than non-RPE firms when contracting on the tested performance metric. Hence, although my earlier results indicate that RPE improves investment efficiency, this positive implication does not appear to translate clearly into higher firm performance. One possible explanation is that I am unable to empirically detect the benefits of RPE in the overall sample.

\subsubsection{Peer Group Common Risk and Firm Performance}

I further investigate the effect of explicit RPE use in compensation plans on firm performance when the common risk captured by peer selection is high because RPE benefits should increase with common risk, as shown in the investment efficiency results in Table 7. Table 8 reports the regression results for TSR performance as a function of peer selection. The coefficient for PEER_COMMONRISK is positive and significant for both one- and two-year TSR $(0.067$, p-value $<0.05 ; 0.342$, p-value $<0.05)$, which indicates that RPE firms selecting peers that capture more common risk demonstrate higher TSR performance on average. With respect to similarity in firm ability, I find a negative and significant coefficient for PEER_DISSIMILARITY for one-year TSR

\footnotetext{
${ }^{15}$ In untabulated results, I find that RPE firms contracting on a measure other than TSR do not have higher TSR than non-RPE firms.
} 
performance, but not for two-year TSR performance. ${ }^{16}$ In untabulated analysis, I reestimate firm performance as a function of RPE use (RPE_USE) for this subsample. The coefficient for RPE_USE is not significant in either 1-year or 2-year TSR performance estimations, which is consistent with the results in Table 7. I also compare the model using the RPE indicator to the model incorporating the common risk captured by selected peers (PEER_COMMONRISK) and peer dissimilarity (PEER_DISSIMILARITY), and find that the second model has smaller AIC and BIC values. This suggests that the specification using peer information is a better fit for the data. Overall, I find evidence consistent with principal-agent theory that predicts that the risk-sharing benefit of RPE increases with more common risk between firm and peers.

\subsection{Additional Analysis}

\subsubsection{RPE Adoption}

As an alternative method to address causality, I further refine the analysis of the effect of RPE use on firm performance by examining firm performance around RPE adoption for firms that begin using RPE in compensation plans. I classify firms as RPE adopters only when they explicitly use RPE in two or more consecutive years upon adoption. This requirement greatly reduces the available sample; after requiring three

\footnotetext{
${ }^{16}$ The findings are similar when I include CEO wealth, vega, and delta variables in the multivariate analysis.
} 
years of post-adoption performance data, my sample is 168 firm-year observations. I use TSR to proxy for firm performance and focus on RPE firms that contract on TSR.

Table 9 reports the results for TSR performance around RPE adoption for RPE contracting on TSR and non-RPE firms. I measure the annual TSR performance in each time period: year before adoption (t-1), first year of adoption ( $\mathrm{t}$ ), second year of adoption $(t+1)$, third year of adoption $(t+2)$. I summarize the adoption timeline in Panel A. The bar graph in Panel B compares the annual TSR performance for RPE and non-RPE observations over time. I include the p-value for the difference in means as well as standard error bars to indicate whether the two groups' averages are statistically different. I find that TSR performance is not statistically different between RPE adopters and non-RPE firms in the year before adoption. In addition, there is no difference between the two groups in the first and second year of adoption. In contrast, RPE firms on average demonstrate higher TSR performance in the third year of adoption, which suggests that RPE use is associated with higher firm performance after RPE adoption, but the effect is not immediate. 


\section{CONCLUSION}

I investigate whether firms incorporating RPE in compensation contracts demonstrate higher investment efficiency and firm performance consistent with better incentive alignment than similar firms that do not use RPE. My study is motivated by principal-agent theory that suggests that the optimal incentive scheme is to compensate managers on the performance of his/her firm relative to that of peer firms when managers are risk-averse and firm performance is affected by common exogenous shocks.

After matching on determinants of RPE use to address selection bias concerns, my results for RPE use and investment efficiency suggest that RPE firms are generally less likely to over- or underinvest, which is consistent with the idea that RPE use motivates managers to make optimal decisions. I also find that the improvement in investment efficiency over non-RPE firms is primarily driven by the use of RPE in compensation contracts and not necessarily a function of common risk captured by selected peers for RPE firms that use custom peer groups. However, I do not find strong evidence that RPE firms have higher firm performance than similar non-RPE firms in the overall sample; RPE firms on average have higher TSR than non-RPE firms only when they contract on TSR performance. Consistent with principal-agent theory, which predicts that RPE benefits depend on the extent of common risk, I find that RPE firms have higher TSR performance than non-RPE firms when common risk is higher for firm and peer performance. RPE firms using a custom peer group perform better than nonRPE firms when the selected peer firms capture more common risk. In sensitivity tests, I 
show that RPE use is associated with higher firm performance after RPE adoption, but the effect is not immediate. Together, these results provide some evidence that RPE use in compensation contracts reduces agency costs and improves incentive alignment. My main results are important because they provide the first empirical evidence that RPE use affects managerial behavior. With the exception of Gong et al. (2011) and Bettis et al. (2014), which use the new disclosures to examine the determinants of RPE use, prior RPE studies focus on whether RPE is used in compensation contracts through implicit tests because firms were not required to disclose the information prior to 2006 . My findings link the predicted benefits of RPE from principal-agent theory to outcomes from RPE use as practiced by examining the explicit use of RPE as disclosed by firms to investment choices and firm performance. I also document the effect of common risk on managers' actions and find some evidence that RPE is more effective in motivating managers when peer performance provides more information about managers' actions than firm performance alone, consistent with theoretical predictions (Holmstrom 1979, 1982; Baiman and Demski 1980) and experimental studies (Frederickson 1992). Future empirical studies on RPE can investigate the effect of RPE use on other managerial decisions or the effect of peer group characteristics on managerial incentives. 


\section{REFERENCES}

Aggarwal, R.K., Samwick, A.A., 1999. Executive compensation, strategic competition, and relative performance evaluation: Theory and evidence. Journal of Finance 54, 1999-2043.

Aggarwal, R.K., Samwick, A.A., 2006. Empire-builders and shirkers: Investment, firm performance, and managerial incentives. Journal of Corporate Finance 12, 489515.

Applied Materials, Inc., 2013. Definitive Proxy Statement. Retrieved from http://www.sec.gov/Archives/edgar/data/6951/000119312513019348/d455405dd ef14a.htm.

Albuquerque, A.M., 2009. Peer firms in relative performance evaluation. Journal of Accounting and Economics 48, 69-89.

Albuquerque, A.M., 2014. Do growth-option firms use less relative performance evaluation? The Accounting Review 89, 27-60.

Albuquerque, A.M., De Franco, G., Verdi, R.S., 2013. Peer choice in CEO compensation. Journal of Financial Economics 108, 160-181.

Antle, R., Smith, A., 1986. An empirical investigation of the relative performance evaluation of corporate executives. Journal of Accounting Research 24, 1-39.

Baber, W.R., Janakiraman, S.N., Kang, S.H., 1996. Investment opportunities and the structure of executive compensation. Journal of Accounting and Economics 21, 297-318.

Baiman, S., Demski, J.S., 1980. Economically optimal performance evaluation and control systems. Journal of Accounting Research 18, 184-220.

Banker, R.D., Huang, R., Natarajan, R., 2011. Equity incentives and long-term value created by SG\&A expenditure. Contemporary Accounting Research 28, 794-830.

Bannister, J., Newman, H., 2003. Analysis of corporate disclosures on relative performance evaluation. Accounting Horizons 17, 235-246.

Bates, T.W., 2005. Asset sales, investment opportunities, and the use of proceeds. Journal of Finance 60, 105-135. 
Berle, A.A., Jr., Means, G.C., 1932. The Modern Corporation and Private Property. New York: Macmillan.

Bettis, C., Bizjak, J., Coles, J., Kalpathy, S., 2010. Stock and option grants with performance-based vesting provisions. Review of Financial Studies 23, 38493888 .

Bettis, J.C., Bizjak, J., Coles, J., Young, B., 2014. Relative performance evaluation in executive compensation contracts. Arizona State University, Texas Christian University, and Mississippi State University. Working paper.

Biddle, G.C., Hilary, G., Verdi, R.S., 2009. How does financial reporting quality relate to investment efficiency? Journal of Accounting and Economics 48, 112-131.

Bizjak, J.M., Lemmon, M.L., Naveen, L., 2008. Does the use of peer groups contribute to higher pay and less efficient compensation? Journal of Financial Economics 90, 152-168.

Bouwens, J., Kroos, P., 2011. Target ratcheting and effort reduction. Journal of Accounting and Economics 51, 171-185.

Cadman, B., Carter, M.E., 2011. Compensation peer groups and their relation with CEO pay. Working Paper. University of Utah and Boston College.

Carter, M.E., Ittner, C.D., Zechman, S.L.C., 2009. Explicit relative performance evaluation in performance-vested equity grants. Review of Accounting Studies 14, 269-306.

Chan, L.K.C., Lakonishok, J., Sougiannis, T., 2001. The stock market valuation of research and development expenditures. Journal of Finance 56, 2431-2456.

Cremers, K.J.M., Nair, V.B., 2005. Governance mechanisms and equity prices. Journal of Finance 60, 2859-2894.

Datta, D.K., Musteen, M., Herrmann, P., 2009. Board characteristics, managerial incentives, and the choice between foreign acquisitions and international joint ventures. Journal of Management 35, 928-953.

Datta, S., Iskandar-Datta, M., Raman, K., 2001. Executive compensation and corporate acquisition decisions. Journal of Finance 56, 2299-2336.

Defeo, V.J., Lambert, R.A., Larcker, D.F., 1989. The executive compensation effects of equity-for-debt swaps. The Accounting Review 64, 201-227.

Dehejia, R.H., Wahba, S., 2002. Propensity score-matching methods for nonexperimental causal studies. Review of Economics and Statistics 84, 151-161. 
Demski, J.S., Feltham, G.A., 1978. Economic incentives in budgetary control systems. The Accounting Review 53, 336-359.

Diamond, D.W., Verrecchia, R.E., 1982. Optimal managerial contracts and equilibrium security prices. Journal of Finance 37, 275-287.

Faulkender, M., Yang, J., 2010. Inside the black box: The role and composition of compensation peer groups. Journal of Financial Economics 96, 257-270.

Frederickson, J.R., 1992. Relative performance information: The effects of common uncertainty and contract type on agent effort. The Accounting Review 67, 647669.

Gibbons, R., Murphy, K.J., 1990. Relative performance evaluation for chief executive officers. Industrial \& Labor Relations Review 43, S30-S51.

Gong, G., Li, L.Y., Shin, J.Y., 2011. Relative performance evaluation and related peer groups in executive compensation contracts. The Accounting Review 86, 10071043.

Grant, J., Markarian, G., Parbonetti, A., 2009. CEO risk-related incentives and income smoothing. Contemporary Accounting Research 26, 1029-1065.

Hannan, R.L., Krishnan, R., Newman, A.H., 2008. The effects of disseminating relative performance feedback in tournament and individual performance compensation plans. The Accounting Review 83, 893-913.

Harris, M., Raviv, A., 1979. Optimal incentive contracts with imperfect information. Journal of Economic Theory 20, 231-259.

Hess Corporation, 2012. Definitive Proxy Statement. Retrieved from http://www.sec.gov/Archives/edgar/data/4447/000119312512128993/d297861dd ef14a.htm.

Holmstrom, B., 1979. Moral hazard and observability. Bell Journal of Economics 10, 74-91.

Holmstrom, B., 1982. Moral hazard in teams. Bell Journal of Economics 13, 324-340.

Huang, R., Marquardt, C., Zhang, B., 2013. Using sales revenue as a performance measure. Working paper, City University of New York-Baruch College and Renmin University of China. 
Hubbard, R.G., 1998. Capital-market imperfections and investment. Journal of Economic Literature 36, 193-225.

Hvide, H.K., 2002. Tournament rewards and risk taking. Journal of Labor Economics 20, 877-898.

Ittner, C.D., Lambert, R.A., Larcker, D.F., 2003. The structure and performance consequences of equity grants to employees of new economy firms. Journal of Accounting and Economics 34, 89-127.

Janakiraman, S.N., Lambert, R.A., Larcker, D.F., 1992. An empirical investigation of the relative performance evaluation hypothesis. Journal of Accounting Research 30, 53-69.

Jensen, M.C., 1986. Agency costs of free cash flow, corporate-finance, and takeovers. American Economic Review 76, 323-329.

Jensen, M.C., Meckling, W.H., 1976. Theory of the firm - Managerial behavior, agency costs and ownership structure. Journal of Financial Economics 3, 305-360.

Jensen, M.C., Murphy, K.J., 1990. Performance pay and top-management incentives. Journal of Political Economy 98, 225-264.

Lambert, R.A., Lanen, W.N., Larcker, D.F., 1989. Executive stock option plans and corporate dividend policy. Journal of Financial and Quantitative Analysis 24, 409-425.

Lamont, O.A., 1997. Cash flow and investment: Evidence from internal capital markets. Journal of Finance 52, 83-109.

Lamont, O.A., 2000. Investment plans and stock returns. Journal of Finance 55, 27192745.

Larcker, D.F., 1983. The association between performance plan adoption and corporate capital-investment. Journal of Accounting and Economics 5, 3-30.

Larcker, D.F., 1987. Short-term compensation contracts and executive expenditure decisions: The case of commercial banks. Journal of Financial and Quantitative Analysis 22, 33-50.

Lazear, E.P., Rosen, S., 1981. Rank-order tournaments as optimum labor contracts. Journal of Political Economy 89, 841-864. 
Leone, A.J., Rock, S., 2002. Empirical tests of budget ratcheting and its effect on managers' discretionary accrual choices. Journal of Accounting and Economics 33, 43-67.

Lev, B., Sougiannis, T., 1996. The capitalization, amortization, and value-relevance of R\&D. Journal of Accounting and Economics 21, 107-138.

Marquardt, C.A., Wiedman, C.I., 2007. Economic consequences of financial reporting changes: diluted EPS and contingent convertible securities. Review of Accounting Studies 12, 487-523.

Matsumura, E.M., Shin, J.Y., 2006. An empirical analysis of an incentive plan with relative performance measures: Evidence from a postal service. The Accounting Review 81, 533-566.

McChesney, R.W., Newman, R., Scott, B., 2005. The Future of Media: Resistance and Reform in the 21st Century. $1^{\text {st }}$ ed. New York: Seven Stories Press.

Morck, R., Shleifer, A., Vishny, R.W., 1990. Do managerial objectives drive bad acquisitions? Journal of Finance 45, 31-48.

Murphy, K.J., 2000. Performance standards in incentive contracts. Journal of Accounting and Economics 30, 245-278.

Nalebuff, B.J., Stiglitz, J.E., 1983. Prizes and incentives - towards a general-theory of compensation and competition. Bell Journal of Economics 14, 21-43.

Richardson, S., 2006. Over-investment of free cash flow. Review of Accounting Studies $11,159-189$.

Rosenbaum, P.R., Rubin, D.B., 1983. The central role of the propensity score in observational studies for causal effects. Biometrika 70, 41-55.

Ross, S.A., 1973. Economic theory of agency - Principals problem. American Economic Review 63, 134-139.

Sanders, W.G., 2001. Behavioral responses of CEOs to stock ownership and stock option pay. Academy of Management Journal 44, 477-492.

Shalev, R., Zhang, I.X., Zhang, Y., 2013. CEO Compensation and Fair Value Accounting: Evidence from Purchase Price Allocation. Journal of Accounting Research 51, 819-854.

Stulz, R.M., 1990. Managerial discretion and optimal financing policies. Journal of Financial Economics 26, 3-27. 
Titman, S., Wei, K.C.J., Xie, F.X., 2004. Capital investments and stock returns. Journal of Financial and Quantitative Analysis 39, 677-700.

Wallace, J.S., 1997. Adopting residual income-based compensation plans: Do you get what you pay for? Journal of Accounting and Economics 24, 275-300.

Weitzman, M.L., 1980. The ratchet principle and performance incentives. Bell Journal of Economics 11, 302-308.

Young, S., Yang, J., 2011. Stock repurchases and executive compensation contract design: The role of earnings per share performance conditions. The Accounting Review 86, 703-733. 


\section{APPENDIX A}

\section{EXAMPLES OF RPE DISCLOSURES}

The following excerpts are taken from the CD\&A of proxy statements filed after the 2006 SEC disclosure changes. These illustrate the different ways that RPE can be implemented.

\section{Hess Corporation (2012)}

In 2012 the compensation and management development committee made significant changes to the company's long-term incentive program for the company's officers, including the NEOs, to bolster the link between pay and performance. In March 2012, the committee changed the long-term incentive award program so that $50 \%$ of the shares awarded annually will be performance share units and the remaining $50 \%$ will be in the form of restricted stock, with stock option awards being eliminated. Payouts on performance share awards will be determined based on the relative performance of the company's TSR over a three-year performance period ending December 31, 2014 compared with that of fifteen peer companies specified in the 2012 Comparator Group on page 21. Payouts of the 2012 performance share awards will range from 0 to $200 \%$ of the target award based on the company's TSR ranking within the peer group as shown below:

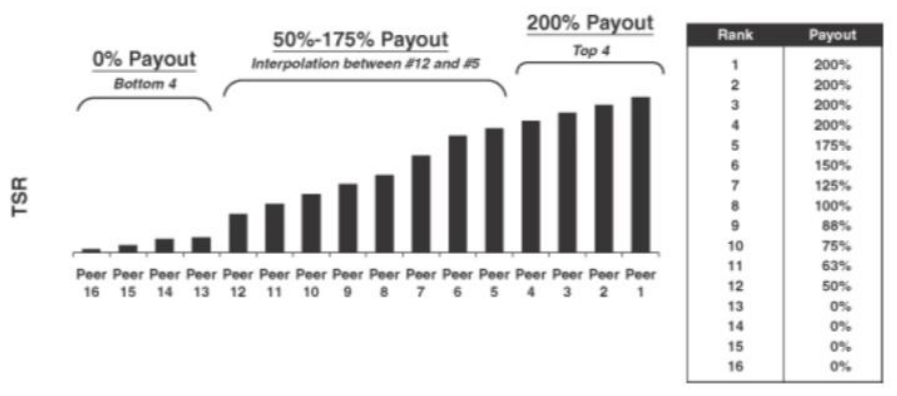

However, in the event that the company's TSR for the performance period is negative, payout for such period will not exceed $100 \%$ of target. In the event the number of peer companies in the peer group including the company is reduced during the performance period by reason of merger, sale, dissolution, bankruptcy or similar circumstances, to 15,14 or 13 , payouts will be made in accordance with alternate payout schedules, and if such number is reduced to fewer than 13 , the compensation and development committee will recalibrate the payouts commensurate with the reduced number. To the extent earned, performance shares will be paid in shares of Hess common stock which will vest and be issued following 
the end of the performance period. Dividend equivalents for the performance period will accrue on performance shares and will only be paid out on earned shares after the performance period. In making these changes to the long-term incentive program, the committee was mindful of the preference of some of the company's stockholders that delivery of long-term incentive compensation be linked in part to attainment of an objective performance metric, and it believes these changes will further reinforce the linkage of the interests of the company's executives with those of the stockholders.

\section{Applied Materials (2012)}

Annual Adjusted Operating Profit Margin Goal. In order for the NEO's fiscal 2012 equity awards to become eligible for time-based vesting, Applied must achieve: (1) positive annual adjusted operating profit margin in any one of fiscal years 2012, 2013, 2014 or 2015, and (2) targeted levels of relative annual adjusted operating profit margin for that same year. We believe these goals are appropriate in light of the cyclical nature of the industries in which we operate. For purposes of calculating fiscal 2012 annual adjusted operating profit margin, the Committee excluded certain charges such as items associated with goodwill impairments and restructuring and asset impairment charges. Assuming the performance goals are met, the NEO must also remain an employee for four years from the grant date in order for all of the shares to vest.

The number of shares eligible to vest (or earned) is determined based upon relative annual adjusted operating profit margin, with no shares eligible to vest unless Applied's annual adjusted operating profit margin is positive and achieves a rank within the peer group of at least the 40th percentile.

\begin{tabular}{|c|c|}
\hline $\begin{array}{c}\text { Percentile Rank of Operating } \\
\text { Profit Margin } \\
\end{array}$ & $\begin{array}{l}\text { Percentage of Shares that } \\
\text { Become Eligible to Vest }\end{array}$ \\
\hline $65^{\text {th }}+$ & $100 \%$ \\
\hline $60^{\text {th }}-64^{\text {th }}$ & $85 \%$ \\
\hline $55^{\text {th }}-59^{\text {th }}$ & $70 \%$ \\
\hline $50^{\text {th }}-54^{\text {th }}$ & $55 \%$ \\
\hline $45^{\text {th }}-49^{\text {th }}$ & $40 \%$ \\
\hline $40^{\text {th }}-44^{\text {th }}$ & $25 \%$ \\
\hline Below $40^{\text {th }}$ & $0 \%$ \\
\hline
\end{tabular}

Total Shareholder Return Goal. In order to focus the NEOs even more intently on creating long-term stockholder value, for the fiscal 2012 performance-based equity awards, the Committee included an additional incentive tied to targeted levels of TSR relative to a peer group comprised of companies in the S\&P 500 IT Index. The TSR goal requires, as a threshold, that Applied's annual adjusted operating profit margin is positive and achieves a rank within the peer group of at least the 40th percentile. In this way, if additional shares become eligible to vest under the TSR goal, NEOs will be rewarded not only for achieving strong operating results, but also 
for creating meaningful additional stockholder value. If annual adjusted operating profit margin goals are achieved and Applied's relative TSR for the two-year period ending on the last day of fiscal 2013 is at least the 60th percentile of the S\&P 500 IT Index, then additional shares will become eligible for time-based vesting, expressed as a percentage of the number of shares earned under the annual adjusted operating profit margin goal, as set forth below.

\begin{tabular}{cc}
$\begin{array}{c}\text { Percentile Rank of Total } \\
\text { Shareholder Return }\end{array}$ & $\begin{array}{c}\text { Percentage of Additional Shares } \\
\text { that Become Eligible to Vest }\end{array}$ \\
\hline $75^{\text {th }}+$ & $50 \%$ \\
$71^{\text {st }}-75^{\text {th }}$ & $40 \%$ \\
$66^{\text {th }}-70^{\text {th }}$ & $30 \%$ \\
$60^{\text {th }}-65^{\text {th }}$ & $20 \%$ \\
Below $60^{\text {th }}$ & $0 \%$
\end{tabular}

Depending on the level of achievement of both the relative operating profit margin and TSR goals, the number of shares that may become eligible to vest under the time-based schedule ranges from $0 \%$ to $150 \%$ of the target number. In order for the maximum number of shares to become eligible to vest, annual adjusted operating profit margin must be at the 65 th percentile or higher within the applicable peer group, and TSR must be at the 75th percentile or higher within the S\&P 500 IT Index. 


\section{APPENDIX B}

\section{VARIABLE DEFINITIONS}

\section{Variable ACTIVIST_INSTOWN}

ANALYSTS

ASSETS

$\mathrm{BM}$

BRD_INDEP

BRD_SIZE

$\mathrm{CASH}$

CASH_FLOW

CEO-CHAIR

CEO_AGE

CEO_WEALTH

COMMON_RISK

COMPCONSULTANT

DIVIDENDS

DIVERSITY_RKADJ
Definition

Ratio of stock owned by activist institutions over total institutional ownership for the firm as defined by Cremers and Nair (2005).

Number of analysts following the firm.

Log of total assets

Total assets divided by the sum of the market value of equity and total liabilities.

Percentage of independent directors serving on the board of directors.

Total number of directors on the board

Cash and scaled by total assets.

Cash flow from operations divided by sales.

Indicator variable equal to 1 if the $\mathrm{CEO}$ is also the Chairman of the Board, and 0 otherwise.

Age of the CEO.

Log of the equity value (stock and options) held by the CEO.

$\mathrm{R}$-squared from regressing the firm's buy-and-hold returns on value-weighted industry return (2-digit SIC) over the 36 month period before the beginning of year $t$.

Indicator variable equal to 1 when the firm uses a compensation consultant to determine executive pay, and 0 otherwise.

Indicator variable equal to 1 if firm pays dividends during the year, and 0 otherwise.

Log of the absolute difference in firm's segment concentration and the median segment concentration for the firm's corresponding decile. Deciles are constructed using firms within the same 2-digit industry based on segment concentration, which is the sum of squares of each segment's sale divided by total segment sales. 
Variable

EPSGROWTH_2YR

EPSGROWTH_3YR

FIRM_AGE

INDUSTRY_CONCENTRATION

INSTOWN

INV_EFF

INVESTMENT

IOS

LEVERAGE

LOSS

MVE

OP_CYCLE

OVERINVESTING

PEER_COMMONRISK

PEER_DISSIMILARITY

\section{Definition}

EPS growth over 2 years. This is calculated as the change in EPS between year $t+1$ and year $t-1$ divided by the absolute value of EPS in year $\mathrm{t}-1$.

EPS growth over 3 years. This is calculated as the change in EPS between year $\mathrm{t}+2$ and year $\mathrm{t}-1$ divided by the absolute value of EPS in year $\mathrm{t}-1$.

Number of years since firm first appeared in Compustat with valid assets.

Sum of squares of firms' market share of sales within each 2-digit SIC industry.

Percentage of firm's stock owned by institutional owners.

Equal to 0 for the benchmark group, 1 for the firms investing below the expected levels, and 2 for the firms investing above the expected levels. Classification is based on the residuals from estimating Equation (2).

Sum of capital expenditures, acquisitions, and $R \& D$, less the sale of property, plant, and equipment

Investment opportunity set scores calculated using factor analysis (Baber et al. 1996).

Sum of short-term and long-term debt divided by total assets.

Indicator variable equal to 1 if net income before extraordinary items less than zero, and 0 otherwise.

Log of market value of equity (common stock outstanding $\times$ closing stock price at end of fiscal year).

Log of receivables/sale plus inventory/cost of goods sold multiplied by 360 .

Indicator variable equal to 1 when a firm-year is classified as overinvesting, and 0 is classified as investing efficiently.

Common risk captured by selected peer group. This is measured as the R-squared from a regression of the firm's stock returns over the prior 36 months on the average returns of the peer group.

Dissimilarity in ability between the firm and the peer group. This is calculated as the absolute value of the firm's market capitalization less the average of the peer group in year $\mathrm{t}-1$. 
Variable

RETURN_INDADJ

RETURN_RKADJ

ROA_INDADJ

ROAGROWTH_2YR

ROAGROWTH_3YR

RPE

RPE_TSR

SALES_GROWTH

SIZE_RKADJ

SLACK

TANGIBILITY

TOP5_INSTOWN

$\Delta$ TOBIN_2YR

$\triangle$ TOBIN_3YR

\section{Definition}

Buy-and-hold annual stock returns less the median buyand-hold annual stock returns for the same 2-digit industry.

Absolute difference in firm's annual stock returns and the median annual stock returns for the firm's corresponding decile. Deciles are constructed using firms within the same 2-digit industry based on annual stock returns.

Return on assets less the median return on assets for the same 2-digit industry.

ROA growth over 2 years. This is calculated as the change in ROA between year $\mathrm{t}+1$ and year $\mathrm{t}-1$ divided by the absolute value of ROA in year $\mathrm{t}-1$.

ROA growth over 3 years. This is calculated as the change in ROA between year $\mathrm{t}+2$ and year $\mathrm{t}-1$ divided by the absolute value of ROA in year $\mathrm{t}-1$.

Indicator variable equal to 1 when a firm-year explicitly uses RPE, and 0 otherwise.

Indicator variable equal to 1 when a firm-year explicitly uses RPE and contracts on TSR, and 0 otherwise.

Percentage change in sales over one year.

Log of the absolute difference in firm's market value of equity and the median market value of equity for the firm's corresponding decile. Deciles are constructed using firms within the same 2-digit industry based on market value of equity.

Cash divided by property, plant and equipment

Property, plant and equipment divided by total assets.

Ratio of stock owned by the top five institutions over total institutional ownership for the firm.

Percentage change in Tobin's Q over 2 years. This is calculated as the change in Tobin's $Q$ between the end of year $t+1$ and beginning of year $t$ divided by Tobin's $Q$ at the beginning of year $t$

Percentage change in Tobin's Q over 2 years. This is calculated as the change in Tobin's $Q$ between the end of year $t+2$ and beginning of year $t$ divided by Tobin's $Q$ at the beginning of year $t$ 
Variable

TSR_1YR

TSR_1YR

TSR_2YR

TSR_3YR

UNDERINVESTING

$\sigma \mathrm{CASH}$ FLOW

бINVESTMENT

oSALES

\section{Definition}

Total shareholder return over one year. This is calculated as the ending share price minus beginning share price plus aggregate dividend payments over the performance period divided by the stock price at the beginning of the performance period.

Annual TSR for year $\mathrm{t}-1$.

Total shareholder return over two years. This is calculated as the ending share price minus beginning share price plus aggregate dividend payments over the performance period divided by the stock price at the beginning of the performance period.

Total shareholder return over three years. This is calculated as the ending share price minus beginning share price plus aggregate dividend payments over the performance period divided by the stock price at the beginning of the performance period.

Indicator variable equal to 1 when a firm-year is classified as underinvesting, and 0 is classified as investing efficiently.

Standard deviation of cash flow from operations scaled by average total assets for years $t-5$ to $t-1$.

Standard deviation of total investment years t-5 to t- 1 .

Standard deviation of sales scaled by average total assets for years $t-5$ to $t-1$. 


\section{APPENDIX C}

\section{TABLES}

\section{TABLE 1}

\section{SAMPLE SELECTION}

Panel A: Sample for propensity-score matching

Firms in Incentive Lab with CEO compensation contract data for 2006-2012 Less firms with fiscal years ending before new disclosure rules (12/15/2006)

Firm-Year Observations Less firms missing data for variables required in propensity-score model Sample of firms available for propensity score matching

8,493

(337)

$\underline{(2,909)}$

5,247

Panel B: Main samples for investment efficiency and firm performance tests

Sample of firms available for propensity score matching

Firm-Year Observations

Less firms missing investment efficiency variables

Less firms not matched in propensity score model

$(1,203)$

Propensity-matched sample for investment efficiency analysis

$\underline{(2,230)}$

1,814

Sample of firms available for propensity score matching

Less firms missing performance data

Less firms not matched in propensity score model

$\underline{(2,485)}$

Full propensity-matched sample for firm performance analysis

2,030 
TABLE 2

RPE USE IN CEO COMPENSATION CONTRACTS

Panel A: Use of RPE in CEO compensation contracts per year

\begin{tabular}{|c|c|c|c|c|c|c|c|c|c|c|c|c|c|c|c|c|}
\hline & \multicolumn{2}{|c|}{2006} & \multicolumn{2}{|c|}{2007} & \multicolumn{2}{|c|}{2008} & \multicolumn{2}{|c|}{2009} & \multicolumn{2}{|c|}{2010} & \multicolumn{2}{|c|}{2011} & \multicolumn{2}{|c|}{2012} & \multicolumn{2}{|c|}{ TOTAL } \\
\hline Non-RPE & 747 & $78.1 \%$ & 1,003 & $79.3 \%$ & 951 & $78.5 \%$ & 930 & $77.1 \%$ & 879 & $73.2 \%$ & 827 & $69.6 \%$ & 714 & $63.4 \%$ & 6,050 & $74.2 \%$ \\
\hline RPE & 209 & $21.9 \%$ & 262 & $20.7 \%$ & 261 & $21.5 \%$ & 277 & $22.9 \%$ & 322 & $26.8 \%$ & 361 & $30.4 \%$ & 413 & $36.6 \%$ & 2,106 & $25.8 \%$ \\
\hline Total & 956 & & 1,265 & & 1,212 & & 1,207 & & 1,201 & & 1,188 & & 1,127 & & 8,156 & \\
\hline
\end{tabular}

Panel B: Number of RPE metrics

\begin{tabular}{ccc} 
Panel B: Number of RPE metrics & \\
\hline NUMBER OF RPE METRICS & NUMBER OF FIRMS & PERCENTAGE \\
\hline 1 & 1,745 & $82.86 \%$ \\
2 & 265 & $12.58 \%$ \\
3 & 81 & $3.85 \%$ \\
4 & 12 & $0.57 \%$ \\
5 & 3 & $0.14 \%$ \\
\hline
\end{tabular}

Panel C: RPE use by award type per year

\begin{tabular}{|c|c|c|c|c|c|c|c|c|c|c|c|c|c|c|c|c|}
\hline & \multicolumn{2}{|c|}{2006} & \multicolumn{2}{|c|}{2007} & \multicolumn{2}{|c|}{2008} & \multicolumn{2}{|c|}{2009} & \multicolumn{2}{|c|}{2010} & \multicolumn{2}{|c|}{2011} & \multicolumn{2}{|c|}{2012} & \multicolumn{2}{|c|}{ TOTAL } \\
\hline Restricted stock & 118 & $56.5 \%$ & 143 & $54.6 \%$ & 162 & $62.1 \%$ & 167 & $60.1 \%$ & 208 & $64.6 \%$ & 249 & $69.0 \%$ & 289 & $70.0 \%$ & 1,336 & $63.4 \%$ \\
\hline Stock options & 2 & $1.0 \%$ & 3 & $1.1 \%$ & 2 & $0.8 \%$ & 2 & $0.7 \%$ & 2 & $0.6 \%$ & 2 & $0.6 \%$ & 1 & $0.2 \%$ & 14 & $0.7 \%$ \\
\hline RSU \& options & 2 & $1.0 \%$ & 1 & $0.4 \%$ & 1 & $0.4 \%$ & 3 & $1.1 \%$ & 2 & $0.6 \%$ & 3 & $0.8 \%$ & 2 & $0.5 \%$ & 14 & $0.7 \%$ \\
\hline Equity Subtotal & $\overline{122}$ & $\overline{58.4 \%}$ & $\overline{147}$ & $\overline{56.1 \%}$ & $\overline{165}$ & $\overline{63.2 \%}$ & $\overline{172}$ & $\overline{61.9 \%}$ & $\overline{212}$ & $\overline{65.8 \%}$ & $\overline{254}$ & $\overline{70.4 \%}$ & $\overline{292}$ & $\overline{70.7 \%}$ & $\overline{1,364}$ & $\overline{64.8 \%}$ \\
\hline Cash only & 64 & $30.6 \%$ & 78 & $29.8 \%$ & 63 & $24.1 \%$ & 73 & $26.3 \%$ & 74 & $23.0 \%$ & 73 & $20.2 \%$ & 78 & $18.9 \%$ & 503 & $23.9 \%$ \\
\hline Cash \& equity & 23 & $11.0 \%$ & 37 & $14.1 \%$ & 33 & $12.6 \%$ & 33 & $11.9 \%$ & 36 & $11.2 \%$ & 34 & $9.4 \%$ & 43 & $10.4 \%$ & 239 & $11.3 \%$ \\
\hline
\end{tabular}

Panel D: Type of peer group used for RPE

PEER GROUP TYPE

Custom peer group

Other index (e.g. S\&P 100, S\&P 500 Property \& Casualty index, NAREIT composite index)

S\&P 500

Custom peer group \& other index

Custom peer group \& S\&P 500

S\&P 500 \& other index

Custom peer group, S\&P $500 \&$ other index

\begin{tabular}{cc} 
NUMBER OF FIRMS & PERCENTAGE \\
\hline 1,380 & $65.53 \%$ \\
366 & $17.38 \%$ \\
193 & $9.16 \%$ \\
79 & $3.67 \%$ \\
43 & $2.04 \%$ \\
33 & $1.57 \%$ \\
12 & $0.57 \%$ \\
\hline
\end{tabular}


TABLE 3

RPE METRICS FOR COMPENSATION CONTRACTS

Panel A: Five most common RPE metrics

\begin{tabular}{lcc}
\hline METRIC & NUMBER OF FIRMS & PERCENTAGE \\
\hline Total shareholder return & 1,631 & $77.45 \%$ \\
ROIC & 166 & $7.88 \%$ \\
EPS growth & 142 & $6.74 \%$ \\
Sales growth & 116 & $5.51 \%$ \\
ROE & 95 & $4.51 \%$ \\
\hline
\end{tabular}

Panel B: Performance metrics for firms-year observations using one or two metrics

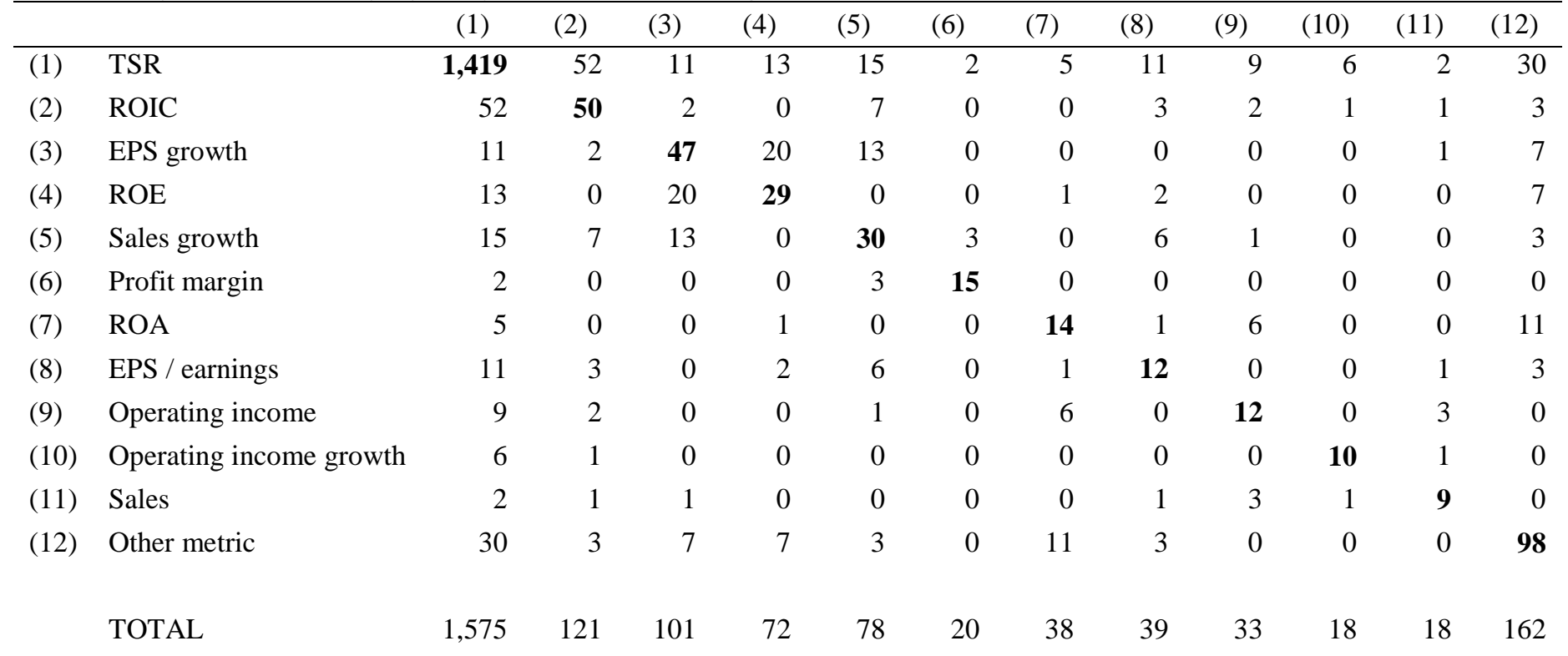

Percentages in Panel A sum to more than $100 \%$ because compensation plans may include more than one RPE component per year.

In Panel B, the values on the diagonal (in bold) are the number of firm-year observations that use one RPE metric. 
TABLE 4

\section{SUMMARY STATISTICS}

Panel A: Summary statistics for RPE firms

\begin{tabular}{|c|c|c|c|c|c|c|c|}
\hline & MEAN & SD & MIN & P25 & MEDIAN & P75 & MAX \\
\hline \multicolumn{8}{|c|}{ Variables for investment efficiency analysis $(\mathrm{N}=907)$} \\
\hline ASSETS $_{\mathrm{t}-1}$ & 8.868 & 1.315 & 6.156 & 7.950 & 8.746 & 9.821 & 12.104 \\
\hline $\mathrm{BM}_{\mathrm{t}-1}$ & 0.656 & 0.247 & 0.158 & 0.469 & 0.636 & 0.845 & 1.230 \\
\hline TANGIBILITY $_{\mathrm{t}-1}$ & 0.305 & 0.221 & 0.017 & 0.130 & 0.240 & 0.442 & 0.872 \\
\hline $\mathrm{CASH}_{-} \mathrm{FLOW}_{\mathrm{t}-1}$ & 0.171 & 0.133 & -0.044 & 0.086 & 0.138 & 0.228 & 0.660 \\
\hline SLACK $_{\mathrm{t}-1}$ & 1.194 & 2.588 & 0.001 & 0.105 & 0.364 & 0.919 & 16.845 \\
\hline OP_CYCLE $E_{t-1}$ & 4.665 & 0.611 & 2.790 & 4.360 & 4.737 & 5.006 & 6.208 \\
\hline $\operatorname{LOSS}_{\mathrm{t}-1}$ & 0.121 & 0.327 & 0 & 0 & 0 & 0 & 1 \\
\hline DIVIDENDS $_{\mathrm{t}-1}$ & 0.700 & 0.458 & 0 & 0 & 1 & 1 & 1 \\
\hline $\sigma \mathrm{CASH}$ _FLOW & 0.026 & 0.023 & 0.002 & 0.011 & 0.019 & 0.034 & 0.118 \\
\hline бSALES & 0.093 & 0.086 & 0.005 & 0.035 & 0.067 & 0.119 & 0.481 \\
\hline бINVESTMENT & 399.677 & 733.046 & 4.229 & 43.783 & 136.249 & 378.579 & $4,811.587$ \\
\hline BRD_SIZE & 10.303 & 1.959 & 6 & 9 & 10 & 12 & 16 \\
\hline BRD_INDEP & 0.841 & 0.086 & 0.556 & 0.800 & 0.875 & 0.900 & 0.929 \\
\hline CEO-CHAIR & 0.605 & 0.489 & 0 & 0 & 1 & 1 & 1 \\
\hline INSTOWN & 0.684 & 0.293 & 0.000 & 0.656 & 0.785 & 0.875 & 0.993 \\
\hline ANALYSTS & 13.216 & 7.881 & 0 & 8 & 12 & 18 & 34 \\
\hline \multicolumn{8}{|c|}{ Variables for firm performance analysis $(\mathrm{N}=1,015)$} \\
\hline RPE_TSR & 0.750 & 0.433 & 0 & 1 & 1 & 1 & 1 \\
\hline TSR_1YR & 0.100 & 0.411 & -0.775 & -0.140 & 0.082 & 0.275 & 1.772 \\
\hline TSR_2YR & 0.202 & 0.609 & -0.846 & -0.175 & 0.106 & 0.479 & 3.292 \\
\hline TSR_1YR $\mathrm{R}_{\mathrm{t}-1}$ & 0.097 & 0.411 & -0.759 & -0.154 & 0.077 & 0.291 & 1.619 \\
\hline BRD_SIZE & 10.452 & 1.977 & 6 & 9 & 10 & 12 & 16 \\
\hline BRD_INDEP & 0.839 & 0.088 & 0.556 & 0.800 & 0.875 & 0.909 & 0.929 \\
\hline LEVERAGE & 0.234 & 0.156 & 0.000 & 0.116 & 0.215 & 0.326 & 0.708 \\
\hline FIRM_AGE & 36.900 & 18.645 & 6 & 19 & 38 & 57 & 63 \\
\hline MVE & 8.859 & 1.237 & 5.787 & 8.001 & 8.689 & 9.646 & 12.191 \\
\hline IOS & -0.047 & 0.008 & -0.057 & -0.052 & -0.049 & -0.044 & -0.011 \\
\hline
\end{tabular}




\section{TABLE 4 (CONTINUED)}

Panel B: Summary statistics for non-RPE firms

\begin{tabular}{|c|c|c|c|c|c|c|c|}
\hline & MEAN & SD & MIN & $\mathrm{P} 25$ & MEDIAN & P75 & MAX \\
\hline \multicolumn{8}{|c|}{ Variables for investment efficiency analysis $(\mathrm{N}=907)$} \\
\hline ASSETS $_{\mathrm{t}-1}$ & 8.842 & 1.198 & 6.156 & 8.005 & 8.701 & 9.635 & 12.104 \\
\hline $\mathrm{BM}_{\mathrm{t}-1}$ & 0.644 & 0.212 & 0.158 & 0.489 & 0.638 & 0.800 & 1.230 \\
\hline TANGIBILITY $_{\mathrm{t}-1}$ & 0.315 & 0.243 & 0.017 & 0.112 & 0.239 & 0.471 & 0.872 \\
\hline $\mathrm{CASH}_{-} \mathrm{FLOW}_{\mathrm{t}-1}$ & 0.169 & 0.140 & -0.044 & 0.083 & 0.125 & 0.215 & 0.660 \\
\hline SLACK $_{\mathrm{t}-1}$ & 1.219 & 2.503 & 0.001 & 0.102 & 0.353 & 1.047 & 16.845 \\
\hline OP_CYCLE $E_{t-1}$ & 4.660 & 0.598 & 2.790 & 4.359 & 4.669 & 4.979 & 6.208 \\
\hline $\operatorname{LOSS}_{\mathrm{t}-1}$ & 0.100 & 0.301 & 0 & 0 & 0 & 0 & 1 \\
\hline DIVIDENDS $_{\mathrm{t}-1}$ & 0.718 & 0.450 & 0 & 0 & 1 & 1 & 1 \\
\hline$\sigma \mathrm{CASH}$ _FLOW & 0.028 & 0.023 & 0.002 & 0.012 & 0.021 & 0.038 & 0.118 \\
\hline$\sigma$ SALES & 0.095 & 0.092 & 0.005 & 0.037 & 0.067 & 0.121 & 0.481 \\
\hline бINVESTMENT & 377.166 & 739.233 & 4.229 & 51.490 & 138.957 & 345.818 & $4,811.587$ \\
\hline CEO-CHAIR & 0.638 & 0.481 & 0 & 0 & 1 & 1 & 1 \\
\hline BRD_SIZE & 10.380 & 2.101 & 6 & 9 & 10 & 12 & 16 \\
\hline BRD_INDEP & 0.836 & 0.086 & 0.556 & 0.800 & 0.875 & 0.900 & 0.929 \\
\hline INSTOWN & 0.703 & 0.280 & 0.000 & 0.669 & 0.803 & 0.876 & 0.993 \\
\hline ANALYSTS & 13.905 & 7.715 & 0 & 8 & 13 & 19 & 34 \\
\hline \multicolumn{8}{|c|}{ Variables for firm performance analysis $(\mathrm{N}=1,015)$} \\
\hline TSR_1YR & 0.080 & 0.413 & -0.775 & -0.157 & 0.082 & 0.264 & 1.772 \\
\hline TSR_2YR & 0.217 & 0.673 & -0.846 & -0.199 & 0.113 & 0.460 & 3.292 \\
\hline TSR_1YR $\mathrm{R}_{\mathrm{t}-1}$ & 0.086 & 0.419 & -0.759 & -0.171 & 0.082 & 0.291 & 1.619 \\
\hline BRD_SIZE & 10.466 & 2.174 & 6 & 9 & 10 & 12 & 16 \\
\hline BRD_INDEP & 0.837 & 0.087 & 0.556 & 0.800 & 0.875 & 0.900 & 0.929 \\
\hline LEVERAGE & 0.248 & 0.164 & 0.000 & 0.126 & 0.227 & 0.354 & 0.708 \\
\hline FIRM_AGE & 35.226 & 18.371 & 6 & 18 & 35 & 54 & 63 \\
\hline MVE & 8.864 & 1.386 & 5.787 & 7.924 & 8.731 & 9.789 & 12.191 \\
\hline IOS & -0.047 & 0.008 & -0.057 & -0.053 & -0.050 & -0.044 & -0.011 \\
\hline
\end{tabular}


TABLE 5

COVARIATE BALANCE FOR RPE AND NON-RPE FIRMS

Panel A: Difference in means for selection variables prior to matching

\begin{tabular}{|c|c|c|c|c|c|}
\hline & \multicolumn{2}{|c|}{$\begin{array}{l}\text { NON-RPE } \\
(\mathrm{N}=3,260)\end{array}$} & \multicolumn{2}{|c|}{$\begin{array}{c}\text { RPE } \\
(\mathrm{N}=1,385)\end{array}$} & \multirow[b]{2}{*}{ Difference in Mean } \\
\hline & Mean & SD & Mean & SD & \\
\hline COMMON_RISK & 0.366 & 0.212 & 0.447 & 0.201 & $-0.082 * * *$ \\
\hline SIZE_RKADJ & 6.893 & 2.034 & 7.293 & 1.948 & $-0.399 * * *$ \\
\hline DIVERSITY_RKADJ & 0.027 & 0.033 & 0.032 & 0.037 & $-0.004 * * *$ \\
\hline RETURN_RKADJ & 0.054 & 0.082 & 0.043 & 0.066 & $0.011 * * *$ \\
\hline INDUSTRY_CONCENTRATION & 0.065 & 0.059 & 0.051 & 0.051 & $0.014 * * *$ \\
\hline BM & 0.622 & 0.262 & 0.709 & 0.220 & $-0.088 * * *$ \\
\hline MVE & 8.434 & 1.298 & 8.927 & 1.232 & $-0.493 * * *$ \\
\hline ROA_INDADJ & 0.054 & 0.104 & 0.047 & 0.093 & $0.007^{*}$ \\
\hline RETURN_INDADJ & 0.103 & 0.358 & 0.073 & 0.284 & $0.029 * *$ \\
\hline CEO_WEALTH & 10.355 & 1.532 & 10.117 & 1.221 & $0.238 * * *$ \\
\hline CEO_AGE & 54.432 & 7.066 & 55.499 & 5.411 & $-1.067 * * *$ \\
\hline TOP5_INSTOWN & 0.320 & 0.133 & 0.313 & 0.121 & 0.008 \\
\hline ACTIVIST_INSTOWN & 0.013 & 0.008 & 0.014 & 0.007 & $-0.001 * * *$ \\
\hline CEO-CHAIR & 0.543 & 0.498 & 0.655 & 0.476 & $-0.112 * * *$ \\
\hline BRD_INDEP & 0.792 & 0.108 & 0.843 & 0.086 & $-0.051 * * *$ \\
\hline BRD_SIZE & 9.823 & 2.264 & 10.643 & 2.038 & $-0.820 * * *$ \\
\hline COMPCONSULTANT & 0.916 & 0.277 & 0.972 & 0.166 & $-0.055^{* * *}$ \\
\hline
\end{tabular}


TABLE 5 (CONTINUED)

Panel B: Difference in means and distribution for selection model variables after matching

\begin{tabular}{|c|c|c|c|c|c|c|}
\hline & \multicolumn{2}{|c|}{$\begin{array}{l}\text { NON-RPE } \\
(\mathrm{N}=1,015)\end{array}$} & \multicolumn{2}{|c|}{$\begin{array}{c}\text { RPE } \\
(\mathrm{N}=1,015)\end{array}$} & \multirow[b]{2}{*}{ Difference in Means } & \multirow[b]{2}{*}{$\begin{array}{c}\text { P-value for } \\
\text { Difference in Distribution }\end{array}$} \\
\hline & Mean & SD & Mean & SD & & \\
\hline COMMON_RISK & 0.434 & 0.217 & 0.428 & 0.204 & 0.006 & 0.25 \\
\hline SIZE_RKADJ & 7.307 & 2.122 & 7.332 & 1.963 & -0.025 & 0.45 \\
\hline DIVERSITY_RKADJ & 0.029 & 0.033 & 0.030 & 0.036 & -0.001 & 0.36 \\
\hline RETURN_RKADJ & 0.048 & 0.074 & 0.049 & 0.072 & -0.001 & 0.64 \\
\hline INDUSTRY_CONCENTRATION & 0.059 & 0.057 & 0.058 & 0.055 & 0.001 & 0.98 \\
\hline $\mathrm{BM}$ & 0.689 & 0.251 & 0.673 & 0.228 & 0.016 & $0.02 * *$ \\
\hline MVE & 8.858 & 1.352 & 8.834 & 1.238 & 0.025 & 0.16 \\
\hline ROA_INDADJ & 0.051 & 0.099 & 0.057 & 0.101 & -0.006 & 0.25 \\
\hline RETURN_INDADJ & 0.086 & 0.315 & 0.088 & 0.307 & -0.003 & 0.33 \\
\hline CEO_WEALTH & 10.271 & 1.341 & 10.233 & 1.185 & 0.039 & $0.03 * *$ \\
\hline CEO_AGE & 55.520 & 6.547 & 55.139 & 5.553 & 0.381 & $0.02 * *$ \\
\hline TOP5_INSTOWN & 0.306 & 0.123 & 0.306 & 0.126 & 0.000 & 0.45 \\
\hline ACTIVIST_INSTOWN & 0.014 & 0.008 & 0.014 & 0.008 & 0.000 & 0.85 \\
\hline CEO-CHAIR & 0.629 & 0.483 & 0.621 & 0.485 & 0.008 & N/A \\
\hline BRD_INDEP & 0.834 & 0.090 & 0.834 & 0.091 & 0.000 & 0.99 \\
\hline BRD_SIZE & 10.444 & 2.236 & 10.419 & 2.056 & 0.026 & 0.64 \\
\hline COMPCONSULTANT & 0.964 & 0.188 & 0.963 & 0.190 & 0.001 & N/A \\
\hline \multicolumn{7}{|c|}{$\begin{array}{l}* * * \mathrm{p}<0.01, * * \mathrm{p}<0.05, * \mathrm{p}<0.10 \text {. } \\
\text { Panel A and B reports the difference in means prior to and after matching, respectively. } \\
\text { Panel B also reports the } \mathrm{p} \text {-values for the Kolmogorov-Smirnov tests of the equality of distributions for continuous variables. } \\
\text { Refer to Appendix B for variable definitions. }\end{array}$} \\
\hline
\end{tabular}


TABLE 6

\section{RPE USE AND DEVIATION FROM EXPECTED INVESTMENT LEVELS}

Panel A: Likelihood of under-/overinvesting as a function of RPE use

\begin{tabular}{|c|c|c|}
\hline VARIABLES & $\begin{array}{c}(1) \\
\text { UNDERINVEST }\end{array}$ & $\begin{array}{c}\text { (2) } \\
\text { OVERINVEST }\end{array}$ \\
\hline RPE & $\begin{array}{l}-0.408 * * * \\
(-2.495)\end{array}$ & $\begin{array}{l}-0.408 * * * \\
(-2.524)\end{array}$ \\
\hline ASSETS $_{\mathrm{t}-1}$ & $\begin{array}{l}0.989 * * * \\
(7.522)\end{array}$ & $\begin{array}{l}0.984 * * * \\
(7.352)\end{array}$ \\
\hline $\mathrm{BM}_{\mathrm{t}-1}$ & $\begin{array}{l}-2.041 * * * \\
(-4.216)\end{array}$ & $\begin{array}{c}-0.251 \\
(-0.555)\end{array}$ \\
\hline TANGIBILITY $_{\mathrm{t}-1}$ & $\begin{array}{l}-1.999 * * * \\
(-2.611)\end{array}$ & $\begin{array}{c}0.160 \\
(0.199)\end{array}$ \\
\hline CASH_FLOW ${ }_{\mathrm{t}-1}$ & $\begin{array}{c}-0.777 \\
(-0.784)\end{array}$ & $\begin{array}{c}-0.415 \\
(-0.400)\end{array}$ \\
\hline $\mathrm{SLACK}_{\mathrm{t}-1}$ & $\begin{array}{c}-0.029 \\
(-0.699)\end{array}$ & $\begin{array}{c}0.037 \\
(1.047)\end{array}$ \\
\hline $\mathrm{OP}_{-} \mathrm{CYCLE} \mathrm{t}_{\mathrm{t}-1}$ & $\begin{array}{l}-0.334 * \\
(-1.661)\end{array}$ & $\begin{array}{l}-0.389 * * \\
(-1.971)\end{array}$ \\
\hline $\operatorname{LOSS}_{\mathrm{t}-1}$ & $\begin{array}{l}-0.462 * \\
(-1.677)\end{array}$ & $\begin{array}{l}-0.630 * * \\
(-2.336)\end{array}$ \\
\hline DIVIDENDS $_{\mathrm{t}-1}$ & $\begin{array}{c}0.079 \\
(0.384)\end{array}$ & $\begin{array}{l}-0.353^{*} \\
(-1.671)\end{array}$ \\
\hline$\sigma \mathrm{CASH}$ _FLOW & $\begin{array}{c}2.412 \\
(0.552)\end{array}$ & $\begin{array}{c}5.481 \\
(1.414)\end{array}$ \\
\hline$\sigma$ SALES & $\begin{array}{c}-0.640 \\
(-0.568)\end{array}$ & $\begin{array}{c}-0.162 \\
(-0.143)\end{array}$ \\
\hline бINVESTMENT & $\begin{array}{c}0.000 \\
(0.686)\end{array}$ & $\begin{array}{c}0.000 \\
(0.569)\end{array}$ \\
\hline BRD_SIZE & $\begin{array}{l}-0.107 * * \\
(-2.308)\end{array}$ & $\begin{array}{c}-0.072 \\
(-1.583)\end{array}$ \\
\hline BRD_INDEP & $\begin{array}{c}-0.301 \\
(-0.265)\end{array}$ & $\begin{array}{c}-0.511 \\
(-0.479)\end{array}$ \\
\hline CEO-CHAIR & $\begin{array}{c}-0.165 \\
(-0.874)\end{array}$ & $\begin{array}{c}-0.076 \\
(-0.404)\end{array}$ \\
\hline INSTOWN & $\begin{array}{c}0.025 \\
(0.101)\end{array}$ & $\begin{array}{c}0.114 \\
(0.453)\end{array}$ \\
\hline ANALYSTS & $\begin{array}{c}0.022 \\
(1.595)\end{array}$ & $\begin{array}{c}0.004 \\
(0.280)\end{array}$ \\
\hline Constant & $\begin{array}{c}-0.843 \\
(-0.445)\end{array}$ & $\begin{array}{l}-3.569 * * \\
(-1.960)\end{array}$ \\
\hline $\begin{array}{l}\text { Observations } \\
\text { Adjusted } \mathrm{R}^{2}\end{array}$ & \multicolumn{2}{|c|}{1,814} \\
\hline
\end{tabular}




\section{TABLE 6 (CONTINUED)}

Panel B: Likelihood of under-loverinvesting for RPE firms using custom peer groups and control firms

\begin{tabular}{|c|c|c|c|c|}
\hline VARIABLES & $\begin{array}{c}(1) \\
\text { UNDERINVEST }\end{array}$ & $\begin{array}{c}(2) \\
\text { OVERINVEST }\end{array}$ & $\begin{array}{c}\text { (3) } \\
\text { UNDERINVEST }\end{array}$ & $\begin{array}{c}\text { (4) } \\
\text { OVERINVEST }\end{array}$ \\
\hline PEER_COMMONRISK & $\begin{array}{l}-1.284 * * * \\
(-3.658)\end{array}$ & $\begin{array}{l}-0.922 * * * \\
(-2.663)\end{array}$ & & \\
\hline PEER_DISSIMILARITY & $\begin{array}{l}-0.015 \\
(-1.320)\end{array}$ & $\begin{array}{l}-0.012 \\
(-1.058)\end{array}$ & & \\
\hline RPE & & & $\begin{array}{l}-0.843 * * * \\
(-4.455)\end{array}$ & $\begin{array}{l}-0.602 * * * \\
(-3.127)\end{array}$ \\
\hline ASSETS $_{\mathrm{t}-1}$ & $\begin{array}{l}1.007 * * * \\
(7.026)\end{array}$ & $\begin{array}{l}0.917 * * * \\
(6.187)\end{array}$ & $\begin{array}{l}0.952 * * * \\
(6.402)\end{array}$ & $\begin{array}{l}0.870 * * * \\
(5.682)\end{array}$ \\
\hline $\mathrm{BM}_{\mathrm{t}-1}$ & $\begin{array}{l}-2.463 * * * \\
(-4.349)\end{array}$ & $\begin{array}{l}-0.753 \\
(-1.357)\end{array}$ & $\begin{array}{l}-2.453 * * * \\
(-4.212)\end{array}$ & $\begin{array}{l}-0.727 \\
(-1.284)\end{array}$ \\
\hline TANGIBILITY $_{\mathrm{t}-1}$ & $\begin{array}{c}0.259 \\
(0.388)\end{array}$ & $\begin{array}{c}0.654 \\
(0.905)\end{array}$ & $\begin{array}{c}0.322 \\
(0.483)\end{array}$ & $\begin{array}{c}0.699 \\
(0.972)\end{array}$ \\
\hline $\mathrm{CASH}_{-} \mathrm{FLOW}_{\mathrm{t}-1}$ & $\begin{array}{c}-0.331 \\
(-0.294)\end{array}$ & $\begin{array}{c}0.010 \\
(0.009)\end{array}$ & $\begin{array}{c}-0.287 \\
(-0.253)\end{array}$ & $\begin{array}{c}0.049 \\
(0.045)\end{array}$ \\
\hline SLACK $_{\mathrm{t}-1}$ & $\begin{array}{c}0.010 \\
(0.263)\end{array}$ & $\begin{array}{l}0.073 * * \\
(2.246)\end{array}$ & $\begin{array}{c}0.011 \\
(0.280)\end{array}$ & $\begin{array}{l}0.073 * * \\
(2.197)\end{array}$ \\
\hline OP_CYCLE ${ }_{t-1}$ & $\begin{array}{c}-0.076 \\
(-0.445)\end{array}$ & $\begin{array}{c}-0.163 \\
(-0.896)\end{array}$ & $\begin{array}{l}-0.078 \\
(-0.461)\end{array}$ & $\begin{array}{l}-0.166 \\
(-0.907)\end{array}$ \\
\hline $\operatorname{LOSS}_{\mathrm{t}-1}$ & $\begin{array}{c}-0.633^{*} \\
(-1.953)\end{array}$ & $\begin{array}{l}-0.684 * * \\
(-2.137)\end{array}$ & $\begin{array}{l}-0.677 * * \\
(-2.111)\end{array}$ & $\begin{array}{l}-0.728^{* *} \\
(-2.291)\end{array}$ \\
\hline DIVIDENDS $_{\mathrm{t}-1}$ & $\begin{array}{c}0.170 \\
(0.726)\end{array}$ & $\begin{array}{c}-0.162 \\
(-0.684)\end{array}$ & $\begin{array}{c}0.158 \\
(0.681)\end{array}$ & $\begin{array}{c}-0.171 \\
(-0.724)\end{array}$ \\
\hline$\sigma \mathrm{CASH}$ _FLOW & $\begin{array}{c}-2.334 \\
(-0.523)\end{array}$ & $\begin{array}{c}4.581 \\
(1.157)\end{array}$ & $\begin{array}{l}-2.626 \\
(-0.591)\end{array}$ & $\begin{array}{c}4.295 \\
(1.091)\end{array}$ \\
\hline$\sigma$ SALES & $\begin{array}{c}0.609 \\
(0.513)\end{array}$ & $\begin{array}{c}-0.579 \\
(-0.463)\end{array}$ & $\begin{array}{c}0.581 \\
(0.496)\end{array}$ & $\begin{array}{c}-0.585 \\
(-0.477)\end{array}$ \\
\hline бINVESTMENT & $\begin{array}{c}0.000 \\
(0.440)\end{array}$ & $\begin{array}{c}0.000 \\
(0.440)\end{array}$ & $\begin{array}{c}0.000 \\
(0.351)\end{array}$ & $\begin{array}{c}0.000 \\
(0.378)\end{array}$ \\
\hline BRD_SIZE & $\begin{array}{l}-0.075 \\
(-1.302)\end{array}$ & $\begin{array}{l}-0.034 \\
(-0.576)\end{array}$ & $\begin{array}{c}-0.074 \\
(-1.264)\end{array}$ & $\begin{array}{c}-0.032 \\
(-0.540)\end{array}$ \\
\hline BRD_INDEP & $\begin{array}{c}1.405 \\
(1.303)\end{array}$ & $\begin{array}{l}2.395^{* *} \\
(2.076)\end{array}$ & $\begin{array}{c}1.378 \\
(1.278)\end{array}$ & $\begin{array}{l}2.364 * * \\
(2.045)\end{array}$ \\
\hline CEO-CHAIR & $\begin{array}{c}0.221 \\
(1.074)\end{array}$ & $\begin{array}{c}0.278 \\
(1.344)\end{array}$ & $\begin{array}{c}0.221 \\
(1.089)\end{array}$ & $\begin{array}{c}0.275 \\
(1.347)\end{array}$ \\
\hline INSTOWN & $\begin{array}{c}-0.024 \\
(-0.076)\end{array}$ & $\begin{array}{c}-0.055 \\
(-0.164)\end{array}$ & $\begin{array}{c}-0.017 \\
(-0.054)\end{array}$ & $\begin{array}{c}-0.047 \\
(-0.140)\end{array}$ \\
\hline ANALYSTS & $\begin{array}{l}-0.002 \\
(-0.123)\end{array}$ & $\begin{array}{c}-0.002 \\
(-0.088)\end{array}$ & $\begin{array}{l}-0.003 \\
(-0.170)\end{array}$ & $\begin{array}{c}-0.002 \\
(-0.132)\end{array}$ \\
\hline Constant & $\begin{array}{l}-6.289 * * * \\
(-4.025)\end{array}$ & $\begin{array}{l}-8.632 * * * \\
(-5.337)\end{array}$ & $\begin{array}{l}-5.549 * * * \\
(-3.503)\end{array}$ & $\begin{array}{l}-8.030 * * * \\
(-4.875)\end{array}$ \\
\hline $\begin{array}{l}\text { Observations } \\
\text { Adjusted R }\end{array}$ & \multicolumn{2}{|c|}{1,212} & \multicolumn{2}{|c|}{1,212} \\
\hline
\end{tabular}


TABLE 6 (CONTINUED)

Panel C: Univariate analysis of investment efficiency and future firm performance

\begin{tabular}{|c|c|c|c|c|c|c|c|}
\hline & $\begin{array}{c}\text { EFFICIENT } \\
\text { INVESTING } \\
(\mathrm{N}=1,028)\end{array}$ & $\begin{array}{l}\text { UNDERINVESTING } \\
(\mathrm{N}=1,808)\end{array}$ & $\begin{array}{c}\text { OVERINVESTING } \\
(\mathrm{N}=1,496)\end{array}$ & \multicolumn{2}{|c|}{$\begin{array}{c}\text { EFFICIENT - } \\
\text { UNDERINVEST } \\
\text { (T-STATISTIC) }\end{array}$} & \multicolumn{2}{|c|}{$\begin{array}{c}\text { EFFICENT - } \\
\text { OVERINVEST } \\
\text { (T-STATISTIC) }\end{array}$} \\
\hline ROAGROWTH_2YR & 0.284 & 0.128 & -0.068 & 0.156 & $(1.40)$ & $0.352 * * *$ & $(2.72)$ \\
\hline ROAGROWTH_2YR & 0.331 & 0.221 & 0.068 & 0.109 & $(0.96)$ & $0.263^{* *}$ & $(2.04)$ \\
\hline EPSGROWTH_2YR & 0.523 & 0.298 & 0.131 & $0.225^{*}$ & $(1.83)$ & $0.392 *$ & $(1.83)$ \\
\hline EPSGROWTH_3YR & 0.523 & 0.363 & 0.234 & 0.160 & $(1.30)$ & 0.289 & $(1.30)$ \\
\hline$\Delta$ TOBIN 2YR & 0.047 & -0.033 & -0.024 & $0.080 * * *$ & $(6.14)$ & $0.071 * * *$ & $(6.14)$ \\
\hline$\triangle \mathrm{TOBIN}^{-} 3 \mathrm{YR}$ & 0.071 & -0.034 & -0.016 & $0.105^{* * *}$ & (7.73) & $0.087 * * *$ & $(7.73)$ \\
\hline
\end{tabular}

$* * * \mathrm{p}<0.01, * * \mathrm{p}<0.05, * \mathrm{p}<0.10$

Panels A and B present multinomial logistic regression of investment efficiency (i.e., likelihood of being above, below or at expected investment levels). Each model is estimated with year and industry fixed effects.

t-statistics are reported in parentheses. They are calculated based on robust standard errors that are adjusted using clustering by firm in Panels A and B

All continuous variables are winsorized at the 1 st and 99th percentiles.

Refer to Appendix B for variable definitions. 
TABLE 7

RPE USE AND TSR PERFORMANCE

Panel A: TSR performance for full propensity-matched sample

\begin{tabular}{|c|c|c|c|c|}
\hline \multirow{2}{*}{$\begin{array}{l}\text { VARIABLES } \\
\text { RPE }\end{array}$} & \multicolumn{2}{|c|}{ TSR_1YR } & \multicolumn{2}{|c|}{$\begin{array}{c}(2) \\
\text { TSR_2YR }\end{array}$} \\
\hline & 0.013 & $(0.913)$ & -0.009 & $(-0.368)$ \\
\hline BRD_SIZE & $-0.021 * * *$ & $(-4.100)$ & $-0.024 * * *$ & $(-2.887)$ \\
\hline BRD_INDEP & 0.131 & (1.372) & 0.190 & $(1.243)$ \\
\hline LEVERAGE & -0.037 & $(-0.522)$ & -0.156 & $(-1.342)$ \\
\hline FIRM_AGE & -0.000 & $(-0.845)$ & -0.000 & $(-0.326)$ \\
\hline MVE & $0.045 * * *$ & $(5.996)$ & $0.027 * *$ & $(2.165)$ \\
\hline TSR_1YR $\mathrm{YR}_{\mathrm{t}-1}$ & $-0.174 * * *$ & $(-6.733)$ & $-0.331 * * *$ & $(-9.499)$ \\
\hline IOS & 0.236 & $(0.185)$ & -0.757 & $(-0.376)$ \\
\hline Constant & -0.112 & $(-0.873)$ & -0.015 & $(-0.075)$ \\
\hline Observations & \multirow{2}{*}{\multicolumn{2}{|c|}{$\begin{array}{l}2,030 \\
0323\end{array}$}} & \multicolumn{2}{|c|}{2,030} \\
\hline Adjusted $\mathrm{R}^{2}$ & & & \multicolumn{2}{|c|}{0.327} \\
\hline
\end{tabular}

Panel B: TSR performance for propensity-matched RPE contracting on TSR and non-RPE firms

\begin{tabular}{|c|c|c|c|c|}
\hline \multirow{2}{*}{$\begin{array}{l}\text { VARIABLES } \\
\text { RPE }\end{array}$} & TSR_1YR & (1) & \multicolumn{2}{|c|}{$(2)$} \\
\hline & $0.037 * *$ & (2.144) & 0.023 & $(0.765)$ \\
\hline BRD_SIZE & $-0.020 * * *$ & $(-3.836)$ & $-0.016 *$ & $(-1.705)$ \\
\hline BRD_INDEP & 0.043 & $(0.364)$ & 0.001 & $(0.004)$ \\
\hline LEVERAGE & -0.099 & $(-1.266)$ & -0.141 & $(-1.063)$ \\
\hline FIRM_AGE & $-0.001 *$ & $(-1.705)$ & -0.000 & $(-0.141)$ \\
\hline MVE & $0.056 * * *$ & $(6.460)$ & $0.030 *$ & (1.882) \\
\hline TSR_1 Y R $\mathrm{t}_{\mathrm{t}-1}$ & $-0.150 * * *$ & $(-5.081)$ & $-0.325 * * *$ & $(-8.105)$ \\
\hline IOS & -1.560 & $(-1.137)$ & $-3.877 *$ & $(-1.739)$ \\
\hline Constant & -0.181 & $(-1.357)$ & 0.079 & $(0.252)$ \\
\hline Observations & \multicolumn{2}{|c|}{1,522} & \multicolumn{2}{|c|}{1,522} \\
\hline Adjusted $\mathrm{R}^{2}$ & \multicolumn{2}{|c|}{0.297} & \multicolumn{2}{|c|}{0.284} \\
\hline
\end{tabular}




\section{TABLE 7 (CONTINUED)}

Panel C: TSR performance for propensity-matched RPE and non-RPE firms contracting on TSR

\begin{tabular}{|c|c|c|c|c|}
\hline \multirow{2}{*}{$\begin{array}{l}\text { VARIABLES } \\
\text { RPE }\end{array}$} & \multicolumn{2}{|c|}{ (1) } & \multicolumn{2}{|c|}{ (2) } \\
\hline & $0.137 * * *$ & $(3.455)$ & $0.066 *$ & (1.118) \\
\hline BRD_SIZE & $-0.068 * * *$ & $(-5.388)$ & $-0.068 * * *$ & $(-2.960)$ \\
\hline BRD_INDEP & 0.364 & (1.586) & 0.074 & $(0.193)$ \\
\hline LEVERAGE & $-0.339 * * *$ & $(-2.644)$ & $-0.509 * *$ & $(-2.242)$ \\
\hline FIRM_AGE & -0.001 & $(-1.110)$ & -0.000 & $(-0.046)$ \\
\hline MVE & $0.100 * * *$ & $(5.362)$ & $0.068 * * *$ & $(2.634)$ \\
\hline TSR_1 YR $\mathrm{T}_{\mathrm{t}-1}$ & $-0.112 *$ & $(-1.975)$ & $-0.275 * * *$ & $(-3.257)$ \\
\hline IOS & $-5.335 * *$ & $(-2.575)$ & -5.113 & $(-1.545)$ \\
\hline Constant & -0.325 & $(-0.987)$ & -0.212 & $(-0.515)$ \\
\hline Observations & \multirow{2}{*}{\multicolumn{2}{|c|}{$\begin{array}{c}218 \\
0.574\end{array}$}} & \multirow{2}{*}{\multicolumn{2}{|c|}{$\begin{array}{c}218 \\
0.427\end{array}$}} \\
\hline Adjusted $\mathrm{R}^{2}$ & & & & \\
\hline \multicolumn{5}{|c|}{$\begin{array}{l}* * * \mathrm{p}<0.01, * * \mathrm{p}<0.05, * \mathrm{p}<0.10 \text {. } \\
\text { Each regression model is estimated with year and industry fixed effects. } \\
\text { t-statistics are reported in parentheses and are calculated based on robust standard errors that are adjusted using clustering by firm. } \\
\text { All continuous variables are winsorized at the } 1 \text { st and } 99 \text { th percentiles. }\end{array}$} \\
\hline
\end{tabular}


TABLE 8

FIRM PERFORMANCE AS A FUNCTION OF COMMON RISK

\begin{tabular}{|c|c|c|c|c|}
\hline \multirow{2}{*}{$\begin{array}{l}\text { VARIABLES } \\
\text { PEER_COMMONRISK }\end{array}$} & \multicolumn{2}{|c|}{$\begin{array}{c}(1) \\
\text { TSR } 1 \mathrm{YR}\end{array}$} & \multicolumn{2}{|c|}{$\begin{array}{c}(2) \\
\text { TSR_2YR }\end{array}$} \\
\hline & $0.067 * *$ & $(2.008)$ & $0.342 * *$ & $(2.240)$ \\
\hline PEER_DISSIMILARITY & $-0.001 * *$ & $(-2.054)$ & 0.000 & $(0.306)$ \\
\hline BRD_SIZE & $-0.024 * * *$ & $(-4.156)$ & -0.015 & $(-1.034)$ \\
\hline BRD_INDEP & 0.105 & $(0.797)$ & -0.101 & $(-0.310)$ \\
\hline LEVERAGE & -0.076 & $(-1.050)$ & -0.107 & $(-0.472)$ \\
\hline FIRM_AGE & -0.000 & $(-0.257)$ & 0.000 & $(0.203)$ \\
\hline MVE & $0.051 * * *$ & $(5.467)$ & 0.008 & $(0.356)$ \\
\hline TSR_1YR $\mathrm{YR}_{\mathrm{t}-1}$ & $-0.186 * * *$ & $(-6.137)$ & $-0.353 * * *$ & $(-6.365)$ \\
\hline IOS & 2.295 & $(1.611)$ & 1.338 & $(0.387)$ \\
\hline Constant & 0.085 & $(0.504)$ & 0.239 & $(0.623)$ \\
\hline Observations & & & & \\
\hline Adjusted $\mathrm{R}^{2}$ & & & & \\
\hline \multicolumn{5}{|c|}{$\begin{array}{l}* * * \mathrm{p}<0.01, * * \mathrm{p}<0.05, * \mathrm{p}<0.10 \text {. } \\
\text { The regressions use a propensity-matched sample of RPE firms benchmarking on a custom peer group and non-RPE firms. } \\
\text { Each regression model is estimated with year and industry fixed effects. } \\
\text { t-statistics are reported in parentheses and are calculated based on robust standard errors that are adjusted using clustering by firm. } \\
\text { All continuous variables are winsorized at the 1st and 99th percentiles. }\end{array}$} \\
\hline
\end{tabular}


TABLE 9

FIRM PERFORMANCE SURROUNDING RPE ADOPTION

Panel A: RPE adoption timeline

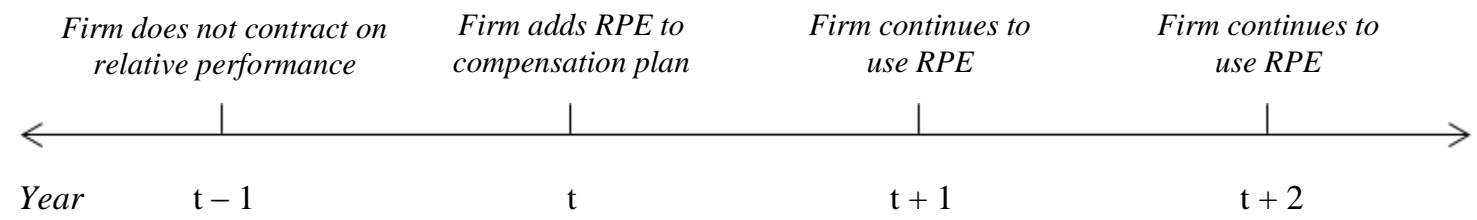

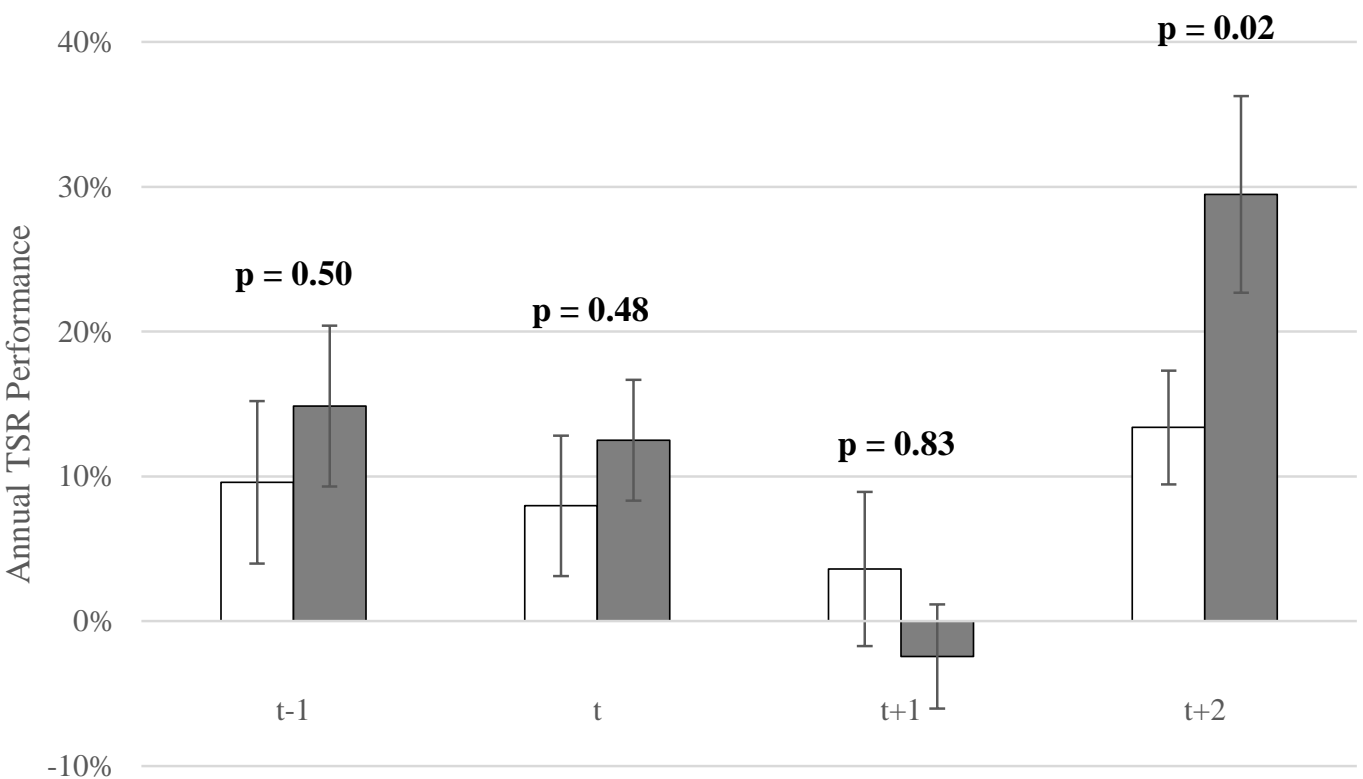

$\square$ Non-RPE (n=84) $\square \operatorname{RPE}(\mathrm{n}=84)$

The sample consists of 84 firms that adopt RPE use and 84 non-RPE firms (propensity-matched) in the year before the switch to RPE (t-1), as well as the first, second, and third year after adoption $(t, t+1$, and $t+2)$.

Standard error bars are included to show whether the average between the two groups are statistically different from each other. 